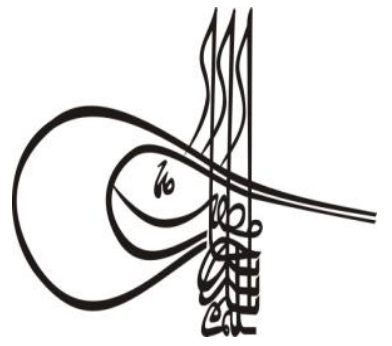

Received/Geliş: 30.08 .2019

\section{Turkigh Studies}

Volume 14 Issue 6, 2019, p. 3145-3166

DOI: 10.29228/TurkishStudies.37888

ISSN: $1308-2140$

Skopje/MACEDONIA-Ankara/TURKEY

Research Article / Araștırma Makalesi

Article Info/Makale Bilgisi

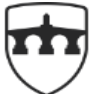

INTERNATIONAL BALKAN UNIVERSITY

EXCELLENCE FOR THE FUTUR IBU.EDU.MK

\Accepted/Kabul: 20.10.2019

Go Report Dates/Rapor Tarihleri: Referee 1 (03.10.2019)-Referee 2 (14.10.2019)

This article was checked by iThenticate.

\title{
AKTİF YAŞLANMA İÇİN “ULUSAL EVDE BAKIM SİSTEMİ”*
}

\author{
Erkan ÇAV $V^{* *}$
}

Öz

Türkiye'nin 65+ yaşlı birey nüfusu, 82 milyon toplam nüfus içerisinde 7 milyonu geçmiş, oranı ise genel nüfusun yaklaşık yüzde 9'una yaklaşmıştır. 26.460 yaşlı bireyin hizmet aldığı huzurevleri temelindeki mevcut kurumsal bakım sistemleri ile bu nüfusun refahı sağlanamaz.

Türkiye, büyüyen yaşlı nüfusa paralel olarak sosyal politikalar ve uygulamalar geliştirmelidir. Böylece, mevcut ve olası sosyal sorunların engellenmesi sağlanır. Dezavantajlı grupların toplumsal refahın oluşumunda belirleyici rolü vardır. Bu dezavantajlı gruplardan biri olan yaşlıların refahını çeşitli uygulamalarla yükseltmek mümkündür. Evde Bakım Sistemi bu uygulamalardan bir tanesidir. Yaşlılar dışında, çocuklar, engelliler, kronik hastalar ve diğer bakım ihtiyacı duyan dezavantajlı gruplar ve bireyler, geçici veya sürekli olarak yararlanacakları evde bakım sistemiyle bireysel refahlarını artırabilirler. Dezavantajlı gruplardaki refah artışı, bütün toplumun refahını artırır. $\mathrm{Bu}$ sebeple, birey ve toplum refahını artıracak "Ulusal Evde Bakım Sistemi"ni (UEBS) öneriyoruz.

$\mathrm{Bu}$ sistem Türkiye'nin aile yapısı, toplumsal dokusu, ekonomik verimlilik, mevcut olanaklar ve genel yaşam tercihleri ile uyumludur. $\mathrm{Bu}$ sistem aynı zamanda "dezavantajlı bireyleri aileleri yanında ve aileleri ile birlikte toplumda refah içinde yaşatma" sosyal hizmet hedefi için ihtiyaç, etkili, sürdürülebilir ve kalıcı bir çözümdür. Bu alt-sistem, ülkenin bütün sosyal hizmet yapılarını, olanaklarını, fonksiyonlarını ve uygulamalarını birbiriyle entegre halinde yönetecek olan üst-sistem "Ulusal Bütünleşik Sosyal Hizmet Sistemi”nin parçası olmalıdır.

Anahtar Kelimeler: Sosyal Hizmet, Dezavantajlı Bireyler, Yaşlı Refahı, Aktif Yaşlanma, Ulusal Evde Bakım Sistemi.

\footnotetext{
* 14 Mart 2019 tarihli, İstanbul'da yapılan 1. Uluslararası Aktif Yaşlanma ve Kuşaklar Arası Dayanışma Kongresi'nde sunulan bildirinin genişletilmiş halidir.

** iD Dr., E-posta: caverkan@gmail.com
} 


\title{
"NATIONAL HOME CARE SYSTEM" FOR ACTIVE AGING
}

\begin{abstract}
Turkey's population of individuals aged $65+$ is 7 million in the 82 million total population, and the ratio was closer to about 9 percent of the general population. With the existing institutional care systems on the basis of nursing homes where 26.460 elderly people receive service, the welfare of this population can not be ensured.

Turkey, a growing elderly population should be developed in parallel with social policies and practices. Thus, existing and potential social problems are prevented. Disadvantaged groups have a decisive role in the formation of social welfare. It is possible to raise the welfare of the elderly, which is one of these disadvantaged groups, with various applications. Home Care System is one of these applications. Apart from the elderly, people with children, disabilities, chronic patients and other disadvantaged groups and individuals who need other care can improve their individual well-being through a home care system that temporary or permanent benefit. The prosperity of disadvantaged groups increases the welfare of the whole society. For this reason, we recommend the "National Home Care System" (NHCS), which will increase the welfare of the individual and the community.

This system is compatible with Turkey's family structure, social fabric, economic efficiency, existing facilities and the general lifestyle choices. The system is also a need, effective, sustainable and lasting solution for the social service goal of "living disadvantaged individuals in their families and all together within sociaty in welfare". This subsystem should be part of the upper-system that is "National Integrated Social Work System" (NISWS), which will manage all social work structures, facilities, functions and practices of the country in an integrated manner.
\end{abstract}

\section{STRUCTURED ABSTRACT}

$65+$ elderly population exceeds 7 million in Turkey, the needs of this population, when we think about both of still working institutional care (nursing homes et al.) and home care practices, data obtained, statistics and findings reveals the inadequacy of some aspects of the existing system. It is a fact that institutional care can not get the needs of the elderly population in need of care. Besides, considering the type of individual and social structure in Turkey, it is seen that institutional care is not the primary preference of people. On the other hand, when the concrete data are examined, it is seen that home care services provided by the existing, central, local, non-governmental organizations and private institutions are inadequate. To get the needs of all disadvantaged groups who need temporary and/or permanent home care, despite the various infrastructural opportunities, it is seen that there is a general inadequacy depending on the organization. In the light of these findings it is possible to say: In Turkey, new solution systems and applications are needed for the 65+ elderly population and all disadvantaged groups in need of home care. Our "National Home 
Care System" offers a viable solution option that can be institutionalized with the existing infrastructure.

In the context of the conditions laid down, the needs of individuals in need of care and the services provided by the care service, the following is clear: Turkey, parallel to the growing elderly population should improve social policies and practices. Thus, existing and potential social problems are prevented. "Home Care System" is one of the applications that extend the solution opportunities in the field of social problem related to aging. Home Care System, not just for elderly people, it is a basic service area and solution implementation for all individuals in need of care (chronic patients, disabled people, individuals with temporary disabilities, children, etc.).

Home care is a fundamental need for elderly, disabled, chronic patients, children and all disadvantaged groups in today's life dynamics. The need for home care is indisputable about individual and community welfare. In this context; for a healthy, peaceful, balanced and active aging that satisfies the satisfaction of elderly people that increase the welfare of elderly; indirectly addressing economic and housing problems, and directly improving health, nutrition, loneliness, isolation and care; supporting, developing and spreading individual and social welfare; completing quantitative inadequate and non-functional institutional care services in terms of the existing social structure; by activating the social relations and social support systems that ensure the healthy integrity of the individual-family-community existence rings by supporting the individual in their own living space, family and society; has the power to directly affect physical, social, emotional, psychological and spiritual well-being while supporting economic and physical well-being; Ministry of Family, Labor and Social Services, Ministry of Health, local administrations, non-governmental organizations, private institutions, voluntary structures etc. coordinated and integrated with all vertical and horizontal health and social work systems; the possibility of acting the activities of public institutions, public and private facilities, or through joint implementation programs of other public, non-governmental organizations, local administrations, private and voluntary institutions that establishment of the "National Home Care System" (NHCS) which includes all of these institutions; is Turkey's family structure, social fabric, economic efficiency of existing facilities and everyday life choices, health and social work needed in the context of objectives, effective, sustainable and permanent solution.

However, one point should be noted: Under the influence of modernization and rising urbanization rate and the effects of urban life related to it, the social structure from traditional family structure to nuclear family and the work of family members, other features such as poor home care support and lack of social insurance support and with under other causes, the family-based home care is not always seen as positive, therefore, it should be foreseen that aging processes in the city may bring other social problems. These cases should be considered when designing the "National Home Care System". On the other side of the world for decades applied at home should benefit from the experience obtained from care system, the results from these places should be used as data for the construction of the system to be configured in Turkey. Ultimately, the "National Home Care System" can 
be designed both by leveraging the world's home care experience on a macro and micro level, and it can provide different solutions for many social problem areas that arise with changing family life.

The "National Home Care System" is a functional structure for all disadvantaged groups and individuals who need and may need disability, temporary or permanent care, but also focus on the need for care of the elderly. Complementary restructuring as "National Integrated Social Work System" will be merged with the "National Home Care System" (NHCS), the effectiveness of the application of health and social work in Turkey, quality, productivity will increase and spread. Thus, the "National Integrated Social Work System" (NISWS), which gathers all social work practices under one roof and aims to keep disadvantaged individuals in the welfare of their families and with their families, can be implemented effectively.

Keywords: Social Work, Disadvantaged Individuals, Elderly Welfare, Active Aging, National Home Care System.

\section{Giriş}

Dezavantajlı grupların toplumsal refahın oluşumunda belirleyici rolü vardır. Bu dezavantajlı gruplardan biri olan yaşlıların refahını çeşitli uygulamalarla yükseltmek mümkündür. Evde Bakım Sistemi bu uygulamalardan bir tanesidir. Yaşlanma, kronolojik, biyolojik, fizyolojik, psikolojik, sosyo-kültürel, ekonomik ve toplumsal özellikleri olan çok boyutlu bir süreçtir (Hablemitoğlu ve Özmete, 2010: 15-21; Kalınkara, 2011: 103-111). Türkiye'de yaşlı nüfus hızla yükselmekte, son beş y1lda bu nüfus \%16 oranında artarak 2018 yılında 7 milyon 186 bin 204 kişiye ulaşmıştır (Istatistiklerle Yaşlılar 2018, 2019, 18 Mart).

Türkiye, büyüyen yaşlı nüfusa paralel olarak bireysel ve toplumsal boyutta etkileri görülen, mevcut ve ilerleyen zamanlarda artması olası sosyal sorunlarının engellenmesi için neler yapmalıdır? Yaşlı bireylerin temel ihtiyaçlarından olan "bakım", çok boyutlu, derinlikli ve detaylı bir konudur. Yaşlı bireylerin tatminlerini karşılayan sağlıklı, huzurlu, dengeli ve aktif bir yaşlanmayı sağlayan yaşlı refahı temelinde kalıcı bir yapılanma, bunun için temeldir. Yaşlılar dışında, çocuklar, engelliler, kronik hastalar ve diğer sebeplerle geçici veya sürekli bakım ihtiyacı duyan dezavantajlı gruplar ve bireyler, evde bakım sistemiyle bireysel refahlarını artırabilirler. Dezavantajlı gruplardaki refah artışı, bütün toplumun refahını artırır.

Bu olgular bütünlüğünde, Türkiye'nin, sosyal hizmet uygulamalarında Evde Bakım Sistemi'ne yoğunlaşarak, sadece yaşlılar için değil, bütün bakıma muhtaç bireylerle ilişkilenen ve onlarla birlikte olan aile üyelerini ve toplamda toplumu, önemli bir sosyal sorun alanından uzaklaştırması, bireysel ve toplumsal yaşam kalitesini artırması mümkündür. "Evde Bakım Sistemi”nin ulusal ölçeğe sahip bir sistem yaklaşımı içerisinde tasarlanması, sadece bu alanın değil bütün sosyal hizmet mekanizmasının ve sosyal hizmetlerin, kalite, kapasite, etkinlik ve verimlilik artışını sağlayabilir. Bunun için, sadece evde bakım sisteminin ulusal düzeyde bütüncül olarak tasarlanması yetmez, sosyal hizmet uygulamalarının da ulusal düzeyde ve bütünleşik olarak tasarlanması ve pratikleriyle yaşama aktarılması gerekir. Çalışmamız, bunun gerekliliğine dikkati çekmeyi amaçlar.

\section{Sosyal Bir Sorun Olarak Yaşlanma ve Yaşlılık}

Yaşlanma ve yaşlılık, sadece bireysel bir süreç olmayıp toplumsal boyutları sebebiyle önemli bir sosyal sorun alanıdır. Sosyal sorun olgusu tanımı ve nelerin sosyal sorun olduğu konusunda her zaman uzlaşma yoktur (Dağdelen, 2016). Yaşlanma ve yaşlılığın, hem sosyal sorunlardan biri, hem de sosyal hizmetin temel alanlarından biri olduğu konusunda ortak bir kabul vardır (Duyan, Sayar ve 
Özbulut, 2008: 178-181). Yaşlı refahı, dezavantajlı gruplardan biri olan yaşlılara yönelik etkili ve kapsamlı sosyal politikalar geliştirilmesi gereken bir alandır (Taşc1, 2014). Bu olgu, bütün dezavantajlı gruplar için geçerlidir.

Türkiye'nin 65+ yaşlı birey nüfusu 7 milyonu aşmış, oranı ise genel nüfusun yaklaşık yüzde 9'una yaklaşmıştır (İstatistiklerle Yaşlılar 2018, 2019, 18 Mart). 2018 yılında yaşlı nüfus oranı \%8,8 olurken, yapılan nüfus projeksiyonlarına göre toplam nüfus içindeki yaşlı nüfus oranının 2023 yılında $\% 10.2,2030$ yılında \%12.9, 2040 yılında, \%16.3, 2060 yılında \%22.6, ve 2080 y1lında \%26.6 olacağ 1 öngörülmektedir (İstatistiklerle Yaşlılar 2018, 2019, 18 Mart). ${ }^{1} 2014$ y1lı verilerine göre, ülkemizde, toplam nüfus içinde \%2.3 oranında en az bir engeli olan yaşlı birey sayısı 1.9 milyondur (İstatistiklerle Yaşlılar 2014, 2015, 18 Mart), tüm nüfustaki toplam engelli birey sayıs1 ise 2011 verilerine göre 4.876.000'dır (Engelli ve Yaşlı Bireylere İlişkin İstatistiki Bilgiler, 2019, Ocak). Öte taraftan, 2018 verilerine göre Türkiye'deki yaşlı nüfusun \%16'sı, yani 1.152.000'i yoksuldur (Engelli ve Yaşlı Bireylere İlişkin İstatistiki Bilgiler, 2019, Ocak). En az bir engeli olan ve/veya yoksul olan yaşl1 bireylerin sosyal hizmet uygulamalarından ve özellikle bakım sistemlerinden yararlanması için güçlü bir uygulama ağına ihtiyaç vardır. Mevcut kurumsal ve evde bakım sistemleri, 1990'lı yıllara göre yaşanan bütün geliştirmelere rağmen, hâlâ her bakımdan, nicelik olarak yeterli değildir. Kurumsal ve evde bakım sistemlerinin farklılıkları temelinde bakıldığında Evde Bakım Sistemi'nin yaşlı bireyler açısından ihtiyacı, önemi ve faydaları kapsamlı olarak karşımıza çıkar (Çavuş, 2013). Dolayısıyla sadece kurum bakımı ile sınırlı bir "bakım" anlayışının, yaşlı bireyler, aileler ve toplum bağlamında genişleyen sosyal sorunların sebeplerinden bir tanesi olması kaçınılmazdır. "Kurum bakımının pahalı olması ve yaşlıyı toplumsal hayattan soyutlaması gibi nedenler günümüzde yaşlının yakın çevresinde kalabilmesine olanak sağlayacak destek hizmetlerinin yaygınlaştırılmasını gerekli kılmaktadır" (Eraslan, Sakarya, Çubukçuoğlu, Ögat, Sevil, Aslan, İnce, Seydibeyoğlu, Tunacan, Eroğlu, Hablemitoğlu, Gönen ve Şengül, 1995). 1995 yılında yapılan 4. Ulusal Sosyal Hizmetler Konferansı'nda dile getirilen bu tespit bugünkü manzarayı ve evde bakım sistemi ihtiyacını on yıllar öncesinden ortaya koyar. Bakım ihtiyacı olan tüm yaşlıları kurum bakımına almak mümkün değildir. ${ }^{2}$ Kurum bakımı, bütün dünyada benzer ekonomik yükler ve sorunlarla baş başadır. Hollanda'da da "bakım hizmetinin kurum dışına taşınması" tartışmaları olmuştur (Laan, 2001). Aynı dönemde, Türkiye'de, 1998 yılında "Yerel Yönetimler ve Sosyal Hizmetler" temalı konunun uzmanı ve paydaşları olan ilgili kişilerden oluşan toplantıda da "yerel ve bölgesel yönetimlerce yaşlıların bakım hizmetlerinin yürütülmesi ve finansmanı" temel konulardan bir tanesi olmuş ve bu konunun önemine dikkat çekilmiştir (Yerel Yönetimler ve Sosyal Hizmetler, 1998: 10). Bakım ihtiyacını kurumlarda karışlamanın maliyeti yaşı ıireyleri kendi yaşam alanlarında desteklemekten çok daha yüksek maddi ve manevî yükler getirir.

Yaşlı refahı düzeyinin korunabilmesi için, mevcut nüfus artışıyla eşzamanlı olarak ilgili hizmetlerin de artması, geliştirilmesi, çeşitlenmesi ve yaygınlaşması gerekir. Evde Bakım Sistemi, yaşlı bireylerin sağlık, beslenme, gündelik faaliyetler, alışveriş, ev içi tasarım, ev onarımı, ev temizliği, sosyal yaşama katılım, temel ihtiyaçların karşılanması ve öz-bakım desteği olarak tanımlanabilecek alt uygulamalar bütünlüğünde yaşlı refahının artışını sağlayan bir sistemdir. Evde Bakım Sistemi aynı zamanda sağlık uygulamalarının temel bir alanıdır (Elbaş ve Arpacı, 2004).

Genel nüfusun \%9'una yaklaşan 65+ yaşı bireylerimizden bakım ihtiyacı olanlar bunu nasıl karşıllyorlar, hangi hizmetleri alıyorlar? Dünyada ve Türkiye'de yaşlıların ekonomik, sosyal ve kültürel koşulları nasıl değişiyor, hangi yeni sorunlarla karşılaşıyorlar, bu sorunları oluşturan ihtiyaçlarını hangi faaliyetlerle, desteklerle, sosyal hizmet uygulamalarıyla karşılıyorlar?

\footnotetext{
${ }^{1}$ Demografik değişimin analizi için bkz. Kalınkara, 2011: 71-95.

${ }^{2}$ Kanada'da yapılan böyle bir karşılaştırmalı inceleme için bkz. Wilkins ve Park, 1998.
} 
Yaşlı nüfusu hızla artan ülkemizde, nüfus artış hızına bağlı olarak sosyal hizmet ve sağlık sistemleri yenilenmez, geliştirilemez ve yaygınlaştırılmaz ise, yapılan iyileştirmelere rağmen hâlâ yaşanan kimi mevcut sorunların artması ve sosyal sorun olarak yaşlanmanın ve yaşlılığın başka sosyal sorunları tetiklemesi ihtimali vardır. Bu olgu, evde bakım ihtiyacı duyan diğer dezavantajlı bireyler için de geçerlidir.

\section{Aktif Yaşlanma ve Sosyal Hizmet İlişkisi}

Dezavantajlı grupların refahını artırmayı hedefleyen sosyal hizmetin alanlarından bir tanesi yaşl1lıktır. Bu alan, bir başka ifadeyle "gerontolojik ve geriatrik sosyal hizmet"tir (Dölek, 2013: 279297). Sosyal hizmet uygulamaları yaşlı refahını destekler, güçlendirir, artırır ve sürekliliğini sağlar (Hablemitoğlu vd., 2010). ${ }^{3}$ Genel olarak tüm bakım süreçlerinin koordinasyonu ve özelde evde bakım sistemi, sosyal hizmet uygulamaları kapsamında yer alır. Sağlık boyutu olmakla birlikte (Çoban ve Esatoğlu, 2004; Elbaş vd., 2004), yaşlı bireyin bedensel, ruhsal ve sosyal bütünlüğü içerisinde bakıldığında evde bakımın sosyal hizmet boyutu da (Çağlar, 2015, 26-28 Kasım), temel öneme sahiptir. Psikolojik ve manevî bütünlük açısından evde bakım hizmeti destekleyicidir (Seyyar, 2007). Yaşlıların ve diğer dezavantajlı bireylerin bu ihtiyaçları; sistematik, nitelikli, düzenli ve sürdürülebilir sosyal hizmet uygulamalarını gerekli kılar.

\section{Sağlık ve Sosyal Hizmet İşbirliği}

"Tıbbî hizmetlerin sosyal hizmetlerle bütünleştirilerek hastanın evinde daha insancıl ortamda bakılması" (Seyyar ve Genç, 2010: 214) olarak sağlık ve sosyal hizmetin kesiştiği bir uygulama olan evde bakım, bu anlamda disiplinlerarası bir uygulamadır. Sağlık bakanlığının mevcut sistemi içerisinde bakım hizmetleri temel bir uygulama alanıdır (Çoban vd., 2004; Elbaş vd., 2004). Örneğin "Aile Hekimliği" kurumunun yaşlı bakımına ilişkin görevleri vardır, haftada bir gün evde ziyaretler yapması, görülen gerekli ihtiyaçlar için uygulama yapması gibi (Elin, 2019, 14 Mart). Türkiye, son yıllarda kapsamlı bir sağlıkta dönüşüm programı uygulamıştır. Aynı şekilde evde sağlık ve bakım uygulamaları konusunda da gelişmeler mevcuttur. ${ }^{4}$ Ancak, yine de mevcut süreçte çeşitli eksiklikler görülmektedir (Bekiroğlu, 2016). Bu eksikliklerin bir kısmı, evde bakım kapsamında inşa edilecek daha kapsamlı bir yapılanma ile, bizim "Ulusal Evde Bakım Sistemi”" (UEBS) olarak önerdiğimiz yapı ile en aza çekilebilir. Böylece evde bakım uygulamasının çok önemli iki ayağı olan sağlık ve sosyal hizmet uygulamalarının bütünlüğü -çeşitli çalışmalarla vurgulandığı gibi (Oğlak, 2016)- sağlanarak, önemli bir yapısal zafiyet giderilmiş olacaktır.

\section{Evde Bakım ve Kurum Bakımı Uygulamaları}

Evde bakım uygulaması, uzun yıllardır uygulanmakta olan ve yaşlılar üzerindeki olumlu etkileri araştırmalarla ortaya konulmuş bir uygulamadır (Caro ve Blank, 1985). Evde bakım uygulaması ile tıbbi bakım maliyetlerinin düşürülmesinin mümkün olduğu da araştırmalarla on yıllar önce ortaya konulmuştur (Weinstein, 1987, Mayıs-Haziran; Cheung, 1988). ${ }^{5}$ Evde bakım uygulamas1, endüstri sonrası toplumdaki refah devletinin temel politika alanlarından bir tanesi olur (Sipila, 2009; Daenzer, 2009; Vukovic, 2013). Yapılan bir araştırmaya göre informel evde bakım yaşliların depresyon riskini azaltmakta ve formel evde bakım ise yaşlıların zihin sağlığını artırabilmektedir

\footnotetext{
${ }^{3}$ Kitabın bütünü bu düşünce üzerine kuruludur.

${ }^{4} \mathrm{Bu}$ alandaki gelişmeler, eksikler ve çözüm önerileri için yapılan kongrelerden biri için bkz. 4. Ulusal ve Uluslararası Katılımlı Evde Sağlık ve Bakım Kongresi (2017, 22-25 Kasım). http://evdebakim.org.tr/4-ulusal-ve-uluslararasi-katilimlievde-saglik-ve-bakim-kongresi.html, İstanbul, E.t. 1 Mart 2019.

${ }^{5}$ Evde bakım uygulaması üzerine küresel ölçekte kapsamlı bir literatür oluşmuştur. Örneğin bu alanda birçok çalışma yapmış ve bu konuda danışmanlık yapan bir uygulayıcın çalışmaları için bkz. Lorna Easterbrook, https://www.lornaeasterbrookconsultancy.com/publications.html, E.t. 31 Mayıs 2019. Kitapları için bkz. Easterbrook (2002; 2007).
} 
(Barnay ve Juin, 2016). ${ }^{6}$ Kurum bakımının zayıf, yetersiz ve eksik olduğu durumlarda ihtiyaçları karşılayan evde bakımın tercih edilmesi bu anlamda belirleyici bir uygulamadır. ${ }^{7}$ Bununla birlikte, evde bakım ile kurum bakımını birbirinin her bakımdan tam alternatifi uygulamalar olarak konumlandırmak hatalı olur. İlgili koşullar, ihtiyaçlar, imkânlar ve talepler bağlamında bu iki bakım sistemi birbirini tamamlayan özellikler içerdiğinden, çatışan değil bütünleyen bakım sistemleridir.

\section{Ulusal Evde Bakım Sistemi (UEBS)}

Evde Bakım Sistemi, yaşlı bireylerin temel gereksinim alanlarından bir tanesidir (Danış, 2004). Son yıllarda bu sağlık ve sosyal hizmet uygulamasının dünyada ve Türkiye'de öne çıktı̆g 1 görülmektedir. "[K]urumsal bakım modelinin alternatifi olarak gelişen evde bakım hizmetleri; yaşlının onuru ve saygınlığını koruyacak, sosyal dışlanmışlığı önleyecek ve yaşadığı ortamda ihtiyacı olan hizmetleri almasını sağlayacak model olarak da ön plana çıkmaktadır” (Oğlak, 2016). Evde Bakım Sistemi'nin ihtiyacı, önemi ve gerekliliği, "Bağımsızlık", "Katılım", "Bakım", "Kendini Gerçekleştirme" ve "Saygınlık" temelinde beş ana başlıkta açıklanan 16 Aralık 1991 tarihli "Birleşmiş Milletler Yaşlı İlkeleri" belgesinde ortaya konulmuştur. "Bakım" başlığı altında şu maddeler sıralanır:

1. Yaşlı bireyler her toplumun kültürel değerler sistemine uygun biçimde aile içi ve toplumsal bakım ve korumadan yararlanmalıdır.

2. Yaşlı bireyler, en iyi bedensel, zihinsel ve duygusal refah düzeyini korumalarına veya bu düzeye ulaşmalarına katkı sağlayacak veya hastalık başlangıcını önleyen veya geciktiren sağlık hizmetlerine erişebilmelidir.

3. Yaşlı bireyler bağımsızlık, sosyal koruma ve bakım düzeylerini iyileştirebilmek için sosyal ve hukuki hizmetlere erişebilmelidir.

4. Yaşlı bireyler, insani ve güvenli bir ortamda sosyal koruma ve rehabilitasyonun yanı sıra sosyal ve zihinsel uyarımlar sunan kurumsal bakım hizmetlerinden uygun düzeyde yararlanabilmelidir.

5. Yaşlı bireyler herhangi bir barınak, bakım veya tedavi merkezinde kalmaları halinde tüm insan hakları ve temel özgürlüklerden yararlanabilmeli; haysiyet, inanç, gereksinim ve mahremiyetlerine mutlak saygı görmeli ve kendi yaşam kaliteleri ve bakımları üzerinde söz sahibi olabilmelidir.

Birinci maddede dile getirilen "Yaşlı bireyler her toplumun kültürel değerler sistemine uygun biçimde aile içi ve toplumsal bakım ve korumadan yararlanmalıdır" ilkesi, önerdiğimiz "Ulusal Evde Bakım Sistemi" için temel yaklaşım noktalarından bir tanesidir. Türkiye'de kurulacak "Ulusal Evde Bakım Sistemi" yaşanılan ve yaşanması muhtemel birçok sorunu çözme olanağına sahiptir. ${ }^{8}$ Evde

\footnotetext{
${ }^{6}$ Demanslı hastalar üzerinde yapılan bir araştırmada aile bireylerine eğitim verilerek gerçekleştirilen evde bakım desteği uygulamasının olumlu etkileri ortaya konulmuştur (Fabris, Molaschi, Aimonino, Ponzetto, Maero, Tibaldi, Nicola, Varetto, Barresi, Cavallero, Boschis, Plastino ve Vitale, 2004)

7 İngiltere'de yapılan bir araştırmada kurum bakımındaki çeşitli yetersizlikler ortaya konularak evde bakım uygulaması ile karşılaştırma yapılır (Fahey, Montgomery, Barnes ve Protheroe, 2003).

${ }^{8}$ Evde bakım konusu üzerine yaptırdığımız derinlemesine görüşmeye dayalı niteliksel bir alan araştırmasında elde edilen bulgular bu yönde sonuçlar vermiştir. Evde Bakım hizmetinden duyulan yüksek memnuniyet yapılan görüşmelerde dile getirilmiştir. Araştırmada, "Evde Bakım Hizmeti Alan Yaşlı İle Yapılan Derinlemesine Görüşme Soru Formu"nda şu sorular sorulmuşstur: 1.Kişisel Bilgiler. 2.Evde Bakımı Alma Sebepleri: 2.1.Tercih mi ettiniz? 2.2.Aile bireylerinin isteği üzerine mi alıyorsunuz? 3.Evde Bakımın Koşulları: 3.1.Kişisel ihtiyaçlarınız sağlanıyor mu? 3.2.Beslenme ihtiyaçlarınız sağlanıyor mu? 3.3.Temizlik, hijyen yeterli düzeyde sağlanıyor mu? 3.4.Sağlanan bu koşullardan memnun musunuz? 4.Evde Kişisel Bakım: 4.1.Hangi durumlarda zorlanıyor ve bir evde bakım elemanına ihtiyaç duyuyorsunuz? 4.2.Bakımınızı yapan kişide cinsiyet özelliğine dikkat ediyor musunuz? 4.3.Doktor, hemșire, hasta bakıcı, psikolog ve sosyal hizmet uzmanı bakım hizmeti esnasında yeterli ilgi ve samimiyeti gösteriyor mu? 4.4.Eksik bulduğunuz ve giderilmesini istediğiniz yönleri var mı? 5.Evde Bakım ve Aile İlișkileri: 5.1.Evde bakım almadan önce ailenizle iliskileriniz nasıldı? 5.2.Evde bakım almaya bașladıktan sonra kendiniz ve ailenizle ilgili ne gibi değişiklikler meydana geldi? 6.Sosyal İlişkiler: 6.1.Evde bakım hizmeti almaya
} 
Bakım Sistemi, "aktif olan bireyler/yaşlılar; aktif olmayan bireylere/yaşlılara göre; yaşlılığa daha iyi uyum sağlar ve daha çok tatmin olurlar" denklemini savunan aktif yaşlanma teorisinin ilkelerini de karşılayarak (Kalınkara, 2011: 27-31), bireylerin yaşlılık dönemlerini en aktif biçimde geçirebilmelerini destekler. Evde Bakım Sistemi, ekonomik ve fiziksel çevre refahına destek olurken temelde fiziksel/bedensel, sosyal, duygusal/psikolojik ve manevi refahı (Hablemitoğlu vd., 2010: 125173) artıran bir sağlık ve sosyal hizmet uygulamasıdır. ${ }^{9}$ Yaşlılıkta yaşam kalitesinin iyileştirilmesi için gerekli hizmetlerden olan "bakım" (Hablemitoğlu vd., 2010: 103), etkili bir Evde Bakım Sistemi ile üst seviyeye çekilebilir. Böylece, yaşlı bireylerin yaşam kalitesini belirleyen tüm koşulların (Kalınkara, 2011: 243-266), bazılarının doğrudan bazılarının ise dolaylı olarak desteklenmesi ile daha yüksek bir yaşam kalitesi sağlanır; ekonomik ve konut sorunlarının dolaylı, sağlık, beslenme, yalnızlık ve izolasyon ve istismar ile "bakım" sorunlarını (Danış, 1994: 19-34) doğrudan "iyileştirme" olanağına sahip, böylece aktif ve "başarılı yaşlanma" (Danış, 1994: 35-37) hedefini güçlendiren bir işleyişe ulaşılır. Evde Bakım Sistemi, aynı zamanda birey-aile-toplum varoluş halkalarının sağlıklı bütünlüğünü sağlayan sosyal ilişkiler ve sosyal destek sistemlerini (Kalınkara, 2011: 157-194) en güçlü biçimde harekete geçirerek yaşlıların aktif günlük yaşamdan uzaklaşmasını ve toplumdan soyutlanmasını engeller. ${ }^{10}$ Nihayetinde ise, bu yapı ile, çeşitli zamanlarda açıklanan Türkiye Kalkınma ve Ulusal Eylem planlarında ortaya konulan hedefler (Kalınkara, 2011: 304-311), bireysel ve toplumsal refah temelinde karşılanabilir. Evde Bakım Sistemi, emeklilik sistemi ve sosyal yardımlar ile birlikte yaşlılara yönelik sosyal refah uygulamalarından bir tanesi (Taşcı, 2014), ancak dile getirdiğimiz sebeplerden dolayı bugün en öne çıkan ihtiyaç, uygulama ve sosyal hizmet alanıdır.

2018 verilerine göre, devlet ve özel huzurevlerinde 26.490 yaşlı birey kurumsal bakım ve 25.133 engelli birey içerisindeki yaşlı bireyler de oranı verilmeden resmi ve özel bakım ve rehabilitasyon merkezlerinde hizmet almaktadır; 709.590 kişi yaşlı maaşı ve yine içindeki yaşlı birey sayısı bilinmeyen 513.276 engelli birey de evde bakım ödemesi almaktadır (Engelli ve Yaşlı Bireylere İlişkin İstatistiki Bilgiler, 2019, Ocak). Yapılan bakım ödemelerinin ne ölçüde saydığımız bakım sistemi kapsamında değerlendirilmesi gerektiği araştırmaya ve kontrole muhtaçtır. Bu ödemeleri alan bireylerin bakım desteğini veren kişiler için yapılacak eğitim sistemi UEBS tarafından düzenlenerek, hem bakım kalitesi artırılır hem de bu alandaki ihmal, istismar ve yetersizlikler en aza indirilebilir. Dolayısıyla, mevcut rakamlar incelendiğinde toplamda kurum bakımı ile yaşlı maaşı veya evde bakım yardımı alan engelli yaşı birey sayısı $736.080 \quad(709.590+26.490)$ ile 1.274 .489 $(26.490+25.133+709.590+513.276)$ arasında bir rakama tekabül etmektedir. Bu rakamın işaret ettiği hizmetin, 7 milyonu aşan 65+ yaşlı nüfus içindeki sosyal hizmet ihtiyacı duyan kesiminin tüm taleplerini karşılaması mümkün değildir. Bu hizmetleri alan yaşlı bireylerin başta bakım olmak üzere

\footnotetext{
başlamanızla sosyal hayatınızda değişme oldu mu? 6.2.Evde bakım hizmeti görevlileri sizi çeşitli etkinliklere yönlendiriyor mu? 7.Hayattan Beklentiler: 7.1.Evde bakım hizmeti almaya başlamanızla sosyal hayatınızda değişme oldu mu? 7.2.Hayata daha mı olumlu baktınız yoksa daha mı olumsuz yaklaştınız? "Evde Bakım Hizmeti Alan Yaşlının Ailesi İle Yapılan Derinlemesine Görüşme Soru Formu"nda ise şu sorular sorulmuştur: 1.Kişisel Bilgiler. 2.Evde bakım hizmeti almaya siz mi yoksa yaşlı birey/bireyleri mi karar verdi? 3. Yaşlı kişi evde bakım hizmeti almaya başladıktan sonra hayatınızda nasıl değişiklikler oldu? 4.Evde bakım hizmeti almaya başlamadan önce yaşlınızın bakımını siz mi üstleniyordunuz? 5.Yaşlı kişiyi niçin kurum bakımına vermeyip evde bakımı tercih ettiniz? 6.Evde bakım hizmeti size maddi ve manevi açıdan zorluk veriyor mu? 7.Bakım hizmeti esnasında sosyal çevrenizden maddi manevi destek alıyor musunuz? Araştırmada Evde Bakım Hizmeti iyileştirme adına yapılan eleştiriler dışında her bakımdan olumlu olarak görülen, ihtiyaç duyulan, yaşam kalitesini ve memnuniyetini artıran ve yaygınlaştırılması gereken bir hizmet olarak dile getirilmiştir (Badur, Seven ve Temel, 2015). Yaptırdığımız bir diğer alan araştırmasında evde bakım hizmeti alımının, göz ardı edilebilir bir seviyede olmadığı gibi, artmasının muhtemel olduğu görülmüştür. Maltepe, Pendik ve Kadıköy ilçelerinde yaşlı yakını olan 150 bireyle yapılan niceliksel yönteme dayalı anketli alan araştırmasında 11 kişi, yani \%7.3 oranında bir kesim yaşlı yakınının evde bakım desteği aldığını belirtmiştir (Aşar, Duman, Kapucu, Turgut ve Yazıcı, 2018). Bu oranın, evde bakım hizmetinin niteliğinin ve hizmet kanallarının geliştirilmesine bağlı olarak niceliğinin genişletilmesi ile artacağı öngörülebilir.

${ }^{9}$ Yaşlılık döneminin psikolojik, sosyal ve bedensel boyutlardan kapsamlı bir değerlendirmesi için bkz. Ersanlı ve Kalkan, 2008. Yaşlılığın sosyal yansımaları için bkz. Sevil, 2005.

${ }^{10}$ Yaşlılara yönelik evde bakım sistemi temelinde ABD'de ileri seviyede yaşlılar ve engelliler için uygulanan bir program için bkz. Zastrow, 2013: 669.
}

\section{Turkish Studies}

Volume 14 Issue 6, 2019 
tüm ihtiyaçlarının karşılandığı varsayılsa bile, toplam nüfus için kalan 6 milyonun üzerindeki yaşlı birey içerisindeki diğer ihtiyaç duyan bireylerin hizmet talepleri ve bakım gereksinimleri, mevcut durumda nasıl ve kimler tarafından karşılanmaktadır? Yaşlı bireyler şöyle sınıflandırılabilir:

1. Aileleri, akrabaları veya yakınları yanında veya onlara yakın bir yerde yaşayıp doğrudan ve/veya dolaylı olarak desteklenenler.

2. Resmi ve resmi olmayan uygulamalar ile bakım elemanları tarafindan doğrudan desteklenenler.

3. İhtiyaçlarını kendileri karşılamaya çalışan bir başına veya aynı duruma olan çift halinde yaşayanlar.

"Türkiye'de yaşlılara yönelik bakım sisteminin özünü yatılı kuruluşlar oluşturmaktadır" (Çağlar, 2015: 218) ${ }^{11}$, ancak rakamların söylediği aynı zamanda şudur: Kurum bakım sistemi ile yaşlılarımızın ihtiyaç duyduğu sağlık ve sosyal hizmet desteğini karşılamak, asla mümkün değildir. 7 milyonun üzerinde bir rakama ulaşan $65+$ bandındaki yaşlı bireyler, sayılanlar dışında hangi başka yaşam sistemi içinde yer alırlarsa alsınlar, nihai noktada bir gün "bakım" ihtiyacı duyacaktır. Bunu sağlamak için, sistematik, kaliteli, esnek, yaygın, etkili, hedefine ulaşan, yaşlı nüfus temelinde birey ve toplum refahını artıran bir Evde Bakım Sistemi gereklidir. Türkiye'deki yaşı bakım modelleri kamu, özel ve sivil toplum olarak yapılanmış olmakla birlikte (Çağlar, 2015: 217-224), mevcut yaşam alanı ve bakım hizmetleri modellerini daha etkili, verimli ve güçlü kılacak ulusal ölçekte bir "Evde Bakım Sistemi" olmalıdır. Sistemin başarısı ulusal düzeydeki örgütlenme kapasitesi ile belirlenecektir. Gelinen noktada, Türkiye'de Sağlık Bakanlığı, Aile, Çalışma ve Sosyal Hizmetler Bakanlığı, yerel yönetimler, sivil toplum kuruluşları, özel kurumlar ve gönüllüler temelinde kurumsallaşan ve ulusal ölçekte yapılandırılacak olan, sosyal hizmet uygulamaları ve sosyal hizmetler odağında örgütlenen bütünleşik bir "Ulusal Evde Bakım Sistemi”ne ihtiyaç vardır.

Önerimiz; Aile, Çalışma ve Sosyal Hizmetler Bakanlığı, Sağlık Bakanlığı, yerel yönetimler, sivil toplum örgütleri, özel kurumlar, gönüllü yapılar vd. tüm dikey ve yatay sağllk ve sosyal hizmet sistemlerinin bu çatı sistem içinde eşgüdümlü ve bütünlüklü olmalarıdır. $\mathrm{Bu}$ sistemde, devlet kurumları tarafindan verilen, kamu ve özel imkanlarla hizmet satın alma yoluyla veya diğer kamu, sivil toplum örgütleri, yerel yönetimler, özel ve gönüllü kurumların ortak uygulama programlarıyla hizmet faaliyetleri karşılanan ve bu kurumların tümünü içeren "Ulusal Evde Bakım Sistemi"nin (UEBS) kurulmasıdır. Bu yapının başarısı ise "Ulusal Bütünleşik Sosyal Hizmet Sistemi” (UBSHS) olarak yapılandırılacak ülke ölçeğindeki bir üst-sistem içinde etkili, kaliteli, verimli, sürdürülebilir ve kalıcı olabilir.

\section{Her Dezavantajlı Grup İçin Geçerli Bir "Ulusal Evde Bakım Sistemi”"}

Ulusal Evde Bakım Sistemi, sadece yaşlı bireyler için değil, bütün bakım ihtiyacı duyan dezavantajlı grupların ve bireylerin faydalanacağı bir sistem olarak tasarlanmalıdır. UEBS, aile desteğini yitiren veya bu desteği zayıf, geçici veya sürekli olarak dezavantajlı duruma düşen bireylerin de destek alacağı sistemdir. Bakıma muhtaç çiftler, yalnız yaşayan yaşlılar, engelli yaşlılar, engelliler, bulaşıcı hastalık sebebiyle yalnız yaşayanlar, evde yatalak olarak yaşayanlar, hastalar, çocuklar vd. dezavantajlı gruplar bu sisteme dahil olabilirler. Evde bakım; "Bakıma ihtiyacı olanlara ve aile fertlerine yaşadıkları ve kendilerini en rahat hissettikleri ortamda ihtiyaçları olan sağlık ve bakım hizmetlerinin sunulmasıdır", "Koruyucu, tedavi edici ve rehabilite edici hizmetlerden bedenî, ruhî ve psiko-sosyal yönden ihtiyaç duyan ve evinde yaşamak isteyen bakıma muhtaç insanlara, multi disipliner hizmet organizasyonu çerçevesinde verilen profesyonel ve kaliteli bakım hizmetleri" (Seyyar, 2010: 214). Bu tanımlar, evde bakım hizmetinin dezavantajlı gruplar bağlamında karşıladığı hizmet yelpazesinin genişliğini ortaya koyar. Evde Bakım Sistemi kapsamında; "sosyal destek

${ }^{11}$ İlgili tez çalışmasının kitap hali için bkz. Çağlar, 2017. 
sistemleri”, “ev bakım desteği”, “etkinlik destekleri”, "sağl1k”, “evde beslenme destekleri” gibi birçok alt uygulama başlıkları vardır. Sağlık hizmetleri, sosyal hizmetler (genel vücut bakımı, yaşlıya yönelik proflaksi/koruyucu önlemler, giyeceklerin ve yatağın bakımı, tuvalet desteği, gıda ve alışveriş desteği), konut bakımı, refakat hizmetleri sürecin temel pratiklerindendir (Aydın, 2005). Başka bir sınıflandırma bunları şöyle tasnif eder: Beden temizliğinin sağlanmasına yönelik destek ve takip hizmetleri (banyo, tırnak kesimi, saç-sakal tıraşı, beslenme); ev idaresine yönelik organizasyon ve temizlik hizmetleri (çamaşırların yıkanması ve ütülenmesi, ilaçların temini, alışveriş, bulaşık yıkama), evde sağlık bakımı, eve yemek götürme, evde sosyal bakım, evde manevi bakım, evde tam gün bakım, ev içi hizmetler, ev tadilatına maddi yardım, ev tamiri tadilatı ve onarım hizmetleri (mekânda güvenli yaşama), psikiyatrik evde bakım vd. (Seyyar, 2010: 215). Karşıladığı ihtiyaçlar temelinde bakıldığında, vurguladığımız sistem, sadece ileri yaşlarda ve bağımlılık düzeyinin arttığı dönemleri kapsamaz, kaza, hastalık vd. herhangi bir sebepten dolayı geçici veya sürekli bakım ihtiyacının duyulduğu her süreçte, bu sistemin devreye girmesi esastır. Bu çerçevede "Evde Bakım Hizmeti", sadece sağlık ile sınırlı olmadığı gibi sosyal hizmet işlemleri dışındaki çeşitli faaliyetleri de kapsar. Bu olgu, bu uygulamaya ihtiyaç duyanların ve duyacakların oranını, genel nüfus içinde $\% 9$ civarında olan $65+$ yaşlı nüfus oranını aşan bir seviyeye çıkarır.

Bakım hizmeti almak için bireyin/yaşlının öz-bakım kapasitesini tamamen kaybetmesi gerekmez. Öz-bakımını tam ve/veya kısmen yapabilen bireyler de daha iyi öz-bakım ve genel yaşam koşulları oluşturabilmek ve gelecekteki olası bedensel, psikolojik, sosyal ve topluma aktif katılım temelli diğer sorunlardan uzak kalabilmek için bu türlü hizmetlerden yaralanabilirler. Bu durum, sağlık ve sosyal hizmet uygulamalarına farklı dezavantajlı grup alanlarına da aktarılabilecek bir çerçeve sunar: Mevcut yaşam kalitesini koruyucu, koşullardan kaynaklanan çeşitli olumsuzlukları önleyici ve toplamda iyilik hâlini artırıcı özelliği olan Evde Bakım Sistemi. Böyle bir sistemden, toplumun bakım ihtiyacı duyan tüm dezavantajlı ve/veya ihtiyaç sahibi bireyleri yaralanabilir. Böylece, birey; birey, aile ve toplum halkalarında yaşanan herhangi bir aksamayı, olumsuzluğu veya yetersizliği bu sistemle aşmayı gerçekleştirebilir. ${ }^{12}$ Evde Bakım Sistemi'ne dahil olanların sosyal destek ihtiyaçları karşılanır, izolasyondan uzak bir yaşama erişirler, sosyal ilişkilerini sürdürebildikleri için topluma uyumları güçlendirilir. Böylece $65+$ üzerinde olan yaşlıların \%80'ninin en az bir, \%50'sinin en az iki kronik rahatsızlığı olduğunu dikkate aldığımızda (Can, 2013: 36-37), yaklaşık 5 milyonun üzerinde yaşı birey ve ülke genelinde 5 milyona ulaşan farklı engelli gruplarının önemli bir bölümü ${ }^{13}$, bunların dışında evde bakıma ihtiyaç duyan veya böyle bir desteği talep eden her yaştan başka dezavantajlı grup üyesi bireyler, hepsi bu hizmetten faydalanabilir. Evde Bakım Sistemi, bu yönüyle "sosyal bakım" uygulamasının bir parçası olur (Oğlak, 2016).

"Bakıma muhtaçlık" bağlamında engellilerin ve yaşlıların durumları sosyal hizmet açısından temel önem taşır (Seyyar, 2006: 131-184). Kronik rahatsızlığı olan ve "fiziki güçsüzlüklerden başlayan ve diğer çeşitli zayıflıklara uzanan bir güçten düşme ile karşı karşıya kalınmaktan başlayıp çeşitli kronik hastalıklara sahip" yaşlılar, "yemek yeme, temel ihtiyaçlarını giderme, alışveriş yapma, insanlarla ilişki kurma, sokağa çıkma, yürüme" gibi temel ihtiyaçlarını dahi yapamayacak durumda olabilmektedirler (Can, 2013: 36-37). Evde bakım sisteminden yararlanan bir diğer dezavantajlı grup olan engelliler bu hizmeti aldığında gündelik yaşamlarında "bağımlı" veya "bağımsız" olmaları temelde değişmez, ancak daha kaliteli bir yaşama ulaşırlar. ${ }^{14}$ Nihayetinde, bağımlı engelliler, kronik hastalığa sahip hastalar, bakıma muhtaç çocuklar ve yaşlılar için Evde Bakım Sistemi, bedensel, psikolojik ve sosyal olarak çok boyutlu biçimde bu bireyleri kuşatarak yaşamsal ihtiyaçlarını karşılar.

\footnotetext{
12 Demanslı yaşlı bireyler için uygulanan aktiviteler, evde bakım sistemlerinde de faydalanılabilecek aktivitlerdir (Yücel, 2009).

132018 verilerine göre, bu engelli bireylerin \%40-69 aras1 engelli olan 341.825’i, \%70 üzeri engeli olup engelli olan 287.726'sı ve 93.000 engelli yakını maaşı ile toplam 723 bin kişi engelli ve engelli yakını maaşı sosyal yardım hizmeti kapsamında yer almaktadır (Engelli ve Yaşlı Bireylere İlişkin İstatistiki Bilgiler, 2019, Ocak).

${ }^{14}$ Bağımlı veya bağımsız olmak engelli bireylerin gündelik yaşamında temel bir konudur (Uluocak ve Aslan, 2012: 83-84).
} 
Evde Bakım Sistemi, hizmeti alan bireyin tüm sorunlarını çözmez, ancak bireyin daha kaliteli bir yaşam sürdürebilmesini sağlayabilir. Evde Bakım Sistemi, bireyi ve aileyi, dolayısıyla dezavantajlı bireyleri ve toplumu güçlendiren bir sosyal hizmet uygulamasını destekler (Bayoğlu, 2011).

Evde Bakım Sistemi'nde, bu alan için eğitilmiş bakım elemanı, aktivite sorumlusu, hemşire, ev yardımcısı, sosyal hizmet uzmanı (sosyal çalışmacı), diyetisyen, psikolog, doktor vd. ihtiyaç olan meslek elemanları, ilgili tekil uygulamalardaki ihtiyaca göre yer alırlar. Bakım ihtiyacı duyan yaşlılara ve engellilere verilen maaşlar ve bakım yardımları ile kayıt-dışı evde bakım elemanları da bu sistemin içinde yer almaktadır. Evde bakım uygulaması, çok boyutlu alt başlıkları sebebiyle disiplinler-arası çalışmayı ve disiplinler-üstü kapsamlı bir yaklaşımı gerektirir.

Türkiye'deki yaşlı refahı anlayışını şöyle özetlemek mümkündür: Yaşlı bireyi; sosyal yaşamdan, günlük faaliyetlerden, yakın akraba ve komşu çevresinden koparmadan, mümkün olduğunca onu kendi alıştı̆ğ, bağlı olduğu, güvende ve iyi hissettiği ortamda yaşamını sürdürebilir olma yönünde, sosyal hizmet uygulamaları ile desteklemek. Sağlık ve Sosyal Hizmet uygulamalarının birlikte yürütülmesi bu sürecin etkinliğini belirler (Evde Sağlık ve Sosyal Hizmetlerin Bütünleşmesi Seтроzуити Raporu, 2013). Çeşitli "Evde Bakım Sistemi” önerileri vardır (Onarcan, 2011, 2 Ağustos). Halihazırda bu alanda, gerçekleştirildiği toplumsal yapılara göre özgün çözümler üreten, ülkelere göre değişen ve uygulanmakta olan farklı "yaşlı bakım modelleri" vardır (İstanbul Yaşlılık Çalıştayı Kitabı, 2012: 15-78). Ülkeler evde bakım sistemlerini kendi sosyodinamik koşullarına ve olanaklarına bağlı olarak oluşturmuş, ülkemizdeki sistemin özellikleri ve mevzuatı da bu çerçevede gelişmiştir (Bilge, Elçioğlu, Ünalcak ve Ünlüoğlu, 2014). ${ }^{15}$ Türkiye'nin ihtiyacı olan sistem; dünyadaki daha iyi örnekleri dikkate alan, bunları geliştiren ve kapsamını genişleten bütünleşik, eşgüdümlü, farklı sağlık ve sosyal hizmet sistemleri ile entegre olan ve bu kurumlarla işbirliği içerisinde işleyen etkili, kaliteli, sürdürülebilir ve kalıcı olan, mevzuatı oluşturulmuş bir "Ulusal Evde Bakım Sistemi"dir.

Evde Bakım Sistemi, dünyada "uzun süreli bakım" olarak geçen 6 aydan yüksek bakım ihtiyacı olan bireylerin durumunu iyileştirmek için esastır. Refahı yüksek veya yükselen ülkeler Evde Bakım Sistemi'nin bakım uygulamasını, kamu birimleriyle yürütme, doğrudan maddi destek veya hizmet alımı yoluyla, sigorta sistemi ile de destekleyerek hayata geçirmiştir (Can, 2013: 38-46). Almanya ${ }^{16}$ ve Japonya'da "bakım sigortası" uygulamaları (Seyyar, 2006: 131-184); İtalya, Fransa, Hollanda, Avusturya, Belçika, İngiltere ve İsveç ülkelerinden bazısının bakım yardımı, bazısının evde bakım desteği, bazısının kurum bakımı veya bu seçeneklerin çeşitli kombinasyonları ile işleyen evde bakım sistemleri vardır (Can, 2013: 37-46). Türkiye; bunları ulusal düzeyde bütünlüklü olarak gerçekleştiren bir organizasyon ve örgütlenme eksiğini en kısa sürede gidermelidir.

\section{Evde Bakım Sistemi Üzerine Eleștiriler, Uygulamadaki Riskli Alanlar ve Dikkat Edilmesi Gereken Olgular}

Evde Bakım Sistemi, bakım ihtiyacı olan bireyi ailesi, yani çevresi içerisinde hizmet almayı sağladığı için toplumsal özelliklerimiz ve "bireyin iyiliğini en üst seviyeye çıkarma" amacıyla uyumlu bir sistemdir. Sosyal hizmet ve sağlık uygulamaları açısından bu konuda, gerek teoride gerekse pratikte büyük ölçüde uzlaş1 vardır (Çoban vd. 2004; Elbaş vd., 2004; Bilge vd, 2014; Çağlar, 2015, 26-28 Kasım). Fakat bununla birlikte, Evde Bakım Sistemi'nin bazı olumsuzluklarına dikkati çeken eleştiriler dikkate alınarak daha etkili bir yapılanma ve uygulama için geliştirmeler de gereklidir. Evde Bakım Sistemi'nde kadın emeğinin istismar edildiği (Gelmez, 2016, 16 Aralık) ve sistemin mantığında bakım yapan kadınların eve bağımlı hale getirilmesi anlayışına dayalı neo-liberal politikalarla biçimlenen cinsiyetçi bir bakış olduğu (Gelmez, 2015), sadece sağlığa dayalı evde bakım

\footnotetext{
15 Türkiye'deki mevzuatın detayları için bkz. Bilge vd., 2014.

16 Yaşlı bakımı alanında her ülke kendi çözümlerini bir şekilde ortaya koymuştur. Örneğin Almanya "Bakım Sigortası" temelli bir model üretmiştir (Çağlar, 2015, 26-28 Kasım).
} 
uygulamasının yaşlı istismarına yol açabilme riskinin bulunduğu (Oğlak, 2016), sistemin sosyal devlet anlayışı gereği toplumda yaygınlaştııılmasındaki yetersizliklere dayalı eşitsizlik durumlarını ve finansmanına yönelik olası riskler içerdiği (Özer ve Şantaş, 2012) şeklindeki olgulara daha yakından bakmak gereklidir.

Evde Bakım Sistemi'nin uygulama detaylarında da birçok riskli alan vardır. Hareket kaybı olan yaşlıların zihinsel ve sosyal kabiliyetleri de zayıflatmaktadır. Mevcut fiziksel terapilerin bütün ihtiyaçları karşılamadığı durumlar için bakım elemanı ile bakım hizmeti alan birey arasında yeni mobilizasyon egzersizleri ihtiyacı ortaya çıkar (Engeström, Nummijoki ve Sannino 2012). Bu açıdan yeni uygulamaların geliştirilebileceği ve geliştirilmesi gereken bir alan Evde Bakım Sistemi. Bunların yanında sadece şehir merkezli bir Evde Bakım Sistemi değil, kırsal alanlardaki yaşlıların bakımı için de çözüm üreten bir sistem gereklidir. ${ }^{17}$ Yaşlıları, evdeki ciddi risklerden korumaya yarayan kapı, yatak, küvet, gaz ve düşme sensörleri vd. alanlardaki sensör uygulamalarını kapsayan teknolojik çözümler (Hori, Nishida, Aizawa, Murakami ve Mizoguchi, 2004; Thiruchelvam ve Teng, 2015) ve yine evde bakım uygulamaları için teknolojik destek sistemleri geliş̧irilmesi uygulamanın başarısına önemli katkılar sağlar (Boissy, Corriveau, Michaud, Labonté ve Royer, 2007). Çevresel faktörlerin sensörlerle kontrolü yanında, biyolojik verilerin de biyo-sensörlerle kontrolü ve bu verilerden hareketle kurum ve evde bakım uygulamalarını geliştirerek yönetme girişimleri vardır (Qadeer, Velik, Zucker ve Boley, 2009). Teknoloji sistemleri eğitim sürecinde de kullanılabilir ve evde bakım eğitimi alan öğrenciler, çeşitli modellerle uygulamayı teknoloji ürünleri desteğiyle öğrenebilirler (Lagana, Malveira, Melo, Silva, Carvalho ve Cabral, 2013). Evde bakım hizmeti alan yaşlıların, yakınları ve onları takip eden meslek elemanları tarafından anlık takibini sağlayan elektronik sistemler de uygulamanın etkinliğini artırır (Nachabe, Girod-Genet, ElHassan ve Khawaja, 2016). Evde bakım uygulaması yapan hemşirelerin (ve elbette diğer meslek elemanlarının), yaşlının konumunu, ihtiyaçlarını, mental ve fiziksel olanaklarını tümüyle kavrayan ve destekleyen bir bakımı uygulayabilecek yetkinliğe sahip olabileceği eğitim programlarından geçmesi temel bir gerekliliktir (Evans, Goodman ve Redfern, 2003). Evde bakım yapan meslek elemanlarının iş yükleri onları strese, hatta depresyona sokabilir (Kesselring, Krulik, Bichsel, Minder, Beck, ve Stuck, 2001). Bu olguyu destekler biçimde evde ve kurumda bakım yapan hemşire-hasta iletişimi analizi yapan bir araştırma, iletişimin etkinliğinin uygulamanın kalitesini belirleyen etkisine işaret eder (Caris-Verhallen, Kerkstra, Heijden ve Bensing, 1998). Evde bakım uygulamasının kalitesini belirleyen farklı meslek elemanlarının rol ve görev dağılımlarının da dikkatle oluşturulması önemlidir (Pajalic, Persson, Westergren ve Skovdahl, 2012). Dolayısıyla evde bakım uygulamasını yapan meslek elemanlarının sadece işlerine uygun kaliteli bir eğitim almaları yetmez, aynı zamanda iletişim becerilerinin hassas, psikolojik dayanıklıklarının sağlam ve değişen koşullara etkili uyum gösterebilen kişisel becerilerinin olması gerekir. Evde bakım altındaki yaşlıların yaşadıkları çeşitli olumsuz içsel psikolojik süreçler de yakından takip edilmelidir (Bruce, McAvay, Raue, Brown, Meyers, Keohane, Jagoda ve Weber, 2002; Kleisiaris, Maniou, Papathanasiou, Sfiniadaki, Collaku, Koutsoumpa ve Sarafis, 2013). Dolayisiyla evde bakım uygulamasının yaşam kalitesi üzerindeki etkileri çok yönlü olarak dikkate alınması gereken alt işlemler ve süreçler içerir (Hellström ve Hallberg, 2001).

Evde Bakım Sistemi’nin kamu bütçesine getirdiği yüklerin doğru yönetilmesi, sistemin etkili, kaliteli ve yaygın olarak işlemesi için öncelikli olmalıdır. Evde Bakım Sistemi'nin bütçe boyutunu oluşturan kamu harcamaları; sosyal yardım uygulamaları ve bu hizmetten yararlanacak bireyi bulunan ailelerin gelir sistemleri ile birlikte düşünülmelidir. ${ }^{18}$ Çocuklar, yaşlılar, engelliler vd. bakıma muhtaç olan ve olacak potansiyel kişilerin gayri resmi bakım sistemleri olarak akrabalar ve komşular ile desteklendiğini ortaya koyan bir araştırma, bu durumun kamu politikalarındaki olası olumsuz

\footnotetext{
17 Kırsal alanlardaki yaşlıların evde bakım uygulamasından yararlanmasına ilişkin bir proje için bkz. Cravens, Mehr, Campbell, Armer, Kruse ve Rubenstein, 2005.

${ }^{18}$ Ailenin tipi, gelir durumu ve mali koşulları ile evde bakım uygulamaları arasındaki bağı inceleyen bir araştırma için bkz. Mou ve Winer, 2012.
} 
yönlendirici etkisine ve evde bakım sistemi uygulamalarının insanı çevreleyen bütün koşullar birleşiminde ele alınması gerektiğine vurgu yapar (Kalwij, Pasini ve Wu, 2009). ABD'de yapılan bir araştırma, evde bakım uygulaması için resmi olmayan bakım elemanlarına ödeme yapan Michigan ve evde bakım kurumlarına ödeme yapan Illinois eyaletlerini karşılaştırmakta ve her iki uygulamanın da avantajlarını ve dezavantajlarını ortaya koyarak, Türkiye'de yapılandırılmasını önerdiğimiz Ulusal Evde Bakım Sistemi için çeşitli fikirler vermektedir (Keigher, Simon-Rusinowitz, Linsk, ve Osterbuch, 1988). Evde Bakım Sistemi kapsamında gönüllülük esasına dayalı çeşitli yerel ve uluslararası projelerin uygulanması da mümkündür. ${ }^{19}$ Bütün bunların bütünlüğünde, temel bir soru daha vardır: Ev ortamı, yaşlanmak için en iyi seçenek midir? Bu soruyu ele alan bir incelemede, eğitim, çocukların korunması ve gençlik bakımı gibi alanlardaki kamu sorumluluğunun yaşlılarda da olması gerektiği vurgulanır (De Lange, 2018). ${ }^{20}$ Sonuç olarak, yaşlılar sadece aile/ev halkının sorumluluğuna bırakılmamalı, bu süreç bir kamu politikası olarak görülerek yaşlılar da koruma altına alınmalıdır. ${ }^{21}$ Gerek mevcut sistem, gerekse bizim önerdiğimiz sistem, burada dile getirilen eleştirileri ve önerileri dikkate alarak toplum ve devlet yapımıza en uygun özelliklerle inşa edilmelidir.

\section{“Ulusal Evde Bakım Sistemi” Neden Gereklidir}

Ortaya çıkan çeşitli olumsuz riskleri en aza indirilerek hayata geçirilecek Ulusal Evde Bakım Sistemi'nin (UEBS) sağladığı uygulama olanakları, bunun getirdiği bireysel ve toplumsal refah artışı, bu alandaki yapısal oluşumun aciliyetini ve önemini ortaya koyar:

1. Evde Bakım Sistemi'nin, bedensel, ruhsal ve sosyal sorunların gelişmesi karşısında “önleyici” özelliği vardır.

2. Toplumsal yapımızın dokusu, özellikleri ve sosyal örgütlenmesi yaşlıların huzurevlerinde bakımını değil, evde bakımını desteklemektedir.

3. Bir sosyal sorun olarak yaşlanmanın ve yaşlılığın profesyonel evde bakım ve destek hizmetleri ile olumsuz etkileri hafifletilerek veya çözülerek toplumsal refah artış1 sağlanır.

4. Bireylerin yaşlılık dönemlerindeki "aktif pozisyonlarını" canlı tutmak esasına dayalı bu yaklaşım, gelecek dönemler için kalıcı bir çözümdür.

5. Bu sistem, çocukların, engelli bireylerin, kronik hastaların ve diğer dezavantajlı bakıma muhtaç olan veya bakım desteği talep eden bireylerin de refahlarını artırmak için işlevseldir.

6. Herhangi bir sebepten dolayı geçici veya sürekli olarak "evde bakım" hizmeti ihtiyacı olan ve bu talepte bulunan her bireyin yaşam koşullarını desteklemek, güçlendirmek ve iyileştirmek için bu sistemin kullanılabilmesi, ülkemizdeki birey ve toplum refahının temelinden sağlamlaştırılması demektir.

Evde Bakım Sistemi, aile bağlarının güçlendirilmesi, gündelik yaşam içinde yaşlı bireylerin varlıklarının desteklenmesi, yürütülmesi ve daha etkin bir hareket imkanı sağlanması sonucu bu bireylerin sosyal olanaklarının güçlendirilmesi ve genişletilmesi ile aktif yaşlanmanın gerçekleştirilebilmesini sağlar. Böylece, yaşlanmaya bağlı ortaya çıkan sosyal sorunlar, büyük ölçüde kontrol altına alınarak, çözüm için kullanılabilecek seçenekler artar. Evde Bakım Sistemi, yaşlı bireyin içinde bulunduğu aile sistemini de destekleyerek, ailenin diğer fertlerinin de refahının artmasını sağlayan, böylece yaşlı birey odağında, çevrenin ve toplumun refahını artıran bir uygulamadır. Hayat kalitesini artırmak isteyen tüm yaşlı bireylerin, engelli ve kronik hasta olanların, çocukların veya diğer

\footnotetext{
19 İngiliz Kızıl Haç Örgütü tarafından Sırbistan-Karadağ bölgesindeki bir “evde bakım programı” değerlendirmesi için bkz. Richmond ve Mias, 2005.

${ }^{20}$ İspanya'da yapılan bir çalışmada da aynı olgu dile getirilir (Otero, Yebenes, Laso ve Victoria, 2003).

${ }^{21}$ Evde Bakım Sistemi yapılanması için önerilen bir evde bakım uygulama ağı yönetim modeli için bkz. Turner, Docherty, Wang ve Campbell, 2009.
} 
gereksinim duyan dezavantajlı bireylerin ihtiyaçlarını karşılayabilecek ş̧ekilde, her ihtiyaç duyulduğunda geçici veya sürekli olarak kullanma imkânı olan bir işleyiş ile oluşturulacak sistem, sağlık ve sosyal hizmet uygulamalarının etkinliğini toplum refahı ile birlikte bütünlüklü olarak artıracaktır.

Dolayısıyla, Türkiye'deki demografik ve sosyolojik değişim kapsamında Evde Bakım Sistemi'nin yaşlı bireylerin ve diğer dezavantajlı bireylerin yaşamlarını destekleyici, yaşam kalitelerini ve tatminlerini koruyucu ve arttırıcı uygulamalarla geliştirilerek yaygınlaştırılması zorunludur. $\mathrm{Bu}$ kapsamda şu öneriler sıralanabilir (Çav, 2015):

1. Yaşlı bireyleri eve bağımlı kılmak odaklı değil, aktivite becerisini geliştirecek bir yaklaşıma dayalı Evde Bakım Sistemi'nin geliştirilmesi.

2. Kamu (ulusal ve yerel), sivil toplum örgütleri, özel, gönüllü ve diğer kurumların yapılarını ilişkilendiren ve uygulamalarını örtüştüren ortak vizyon ile uygulamada eşgüdüm ve işbirliğini esas alan "bütünleşik yaklaşıma” dayalı bir yapılanma oluşturulması.

3. Uluslararası uygulamalardan da faydalanılarak, Türkiye'deki farklı uygulamalarda temel alınacak ortak bir Evde Bakım Hizmeti Standartları'nın geliştirilmesi.

4. Evde Bakım Sistemi'ni; engelli, çocuk, süreğen hastalıklı ve/veya yaşam kalitesini korumak ve arttırmak ihtiyacı duyan farklı gruplar için de kullanılabilir olarak tasarlayacak, genişletecek ve yaygınlaştıracak bir perspektifin ve alt-yapının oluşturulması.

\section{"Ulusal Evde Bakım Sistemi"ni de Kapsayan "Ulusal Bütünleşik Sosyal Hizmet Sistemi"nin Faydaları}

Ulusal Evde Bakım Sistemi ile birlikte dile getirilmesi gereken bir diğer kurumsal yapılanma ihtiyac1 "Ulusal Bütünleşik Sosyal Hizmet Sistemi"dir. Öz itibariyle ortaya koymak gerekirse, sadece "Ulusal Evde Bakım Sistemi" değil, çocuk, kadın, engelli ve diğer tüm dezavantajlı gruplar için de ayrı ayrı kurumlaştırılacak sistemlerin birbiriyle paralel ve şemsiye yapı olarak "Ulusal Bütünleşik Sosyal Hizmet Sistemi" kapsamında "çatı" bir kurumsal sistemde birleştirilmesi; birey, toplum ve devlet organizasyonu düzeylerinde kat kat genişleyen önemli avantajlar getirerek şunları sağlar:

1. Maddî ve manevî tüm kaynakların doğru biçimde kullanılması, verimliliğin sağlanması, hedef odaklı hizmet ve maliyetlerin optimumda tutulması: Hizmet için gerekli bütün kaynakların ilgili uygulamanın duyduğu ihtiyaç ölçüsünde, yerinde, nitel ve nicel olarak gerektiği kadar kullanılması.

2. Hızlı, uygun ve ihtiyaç duyulan hizmetin seçilmesi: Kamu, yerel yönetim, sivil toplum, özel veya gönüllü kurumlardaki tüm meslek elemanlarının/kadroların verilecek hizmetler için en uygun, doğru ve etkili olacak biçimde yönetilmesi; sahada, ihtiyaç duyulan hizmete uygun meslek elemanlarının doğru uygulamalara yönlendirilmesi.

3. Mükerrer hizmetlerin ortadan kaldırılarak daha çok kişiye ulaşan adil, makûl, etkili, sürdürülebilir ve kalıcı hizmetlerin sunulması.

4. Hızlı, kaliteli, etkili, yerinde ve çözüm odaklı olan memnuniyeti yüksek hizmetlerin gerçekleştirilmesi.

5. Denetlenebilir ve hesap verilebilir, şeffaf, kaliteli, etkili, sürdürülebilir ve kalıcı bir sistemin kurulmas1.

6. "Ulusal Evde Bakım Sistemi” (UEBS) ve diğer tüm dezavantajlı grupları kapsayan farklı hizmet sistemleri ile "Ulusal Bütünleşik Sosyal Hizmet Sistemi”nin (UBSHS) uyumlu, eşgüdümlü, etkili, kaliteli ve başarılı olarak yönetilmesi. 


\section{0. ve 11. Kalkınma Planlarında "Evde Bakım Sistemi"}

Devlet, bütün ilgili kurumlarında Evde Bakım Sistemi'nin önemi noktasında yüksek bir farkındalığa, bilince, birikime, sistem inşa etme ve uygulayabilme alt-yapısına sahiptir. 10. Kalkınma Planı'nda (2014-2018) Evde Bakım Sistemi konusunda kapsamlı bir öneri sistemi olduğu gibi, bu öneriler 11. Kalkınma Planı'nda (2019-2023) genişletilmiş ve geliştirilmiştir. Önerimiz olan "Ulusal Evde Bakım Sistemi”, bu mevcut alt-yapı ile temelleri sağlam, faaliyetleri etkili ve toplumda karşı1lı̆ı olan somut uygulamalarla hayata geçirilebilir.

10. Kalkınma Planı (2014-2018) Yaşlanma Özel İhtisas Komisyonu Raporu'nda “Evde Bakım Hizmeti", "Yaşlı Bakım Hizmetleri" altında "Kurumsal Bakım Hizmeti" ile birlikte yer alan iki başlıktan biri olarak ele alınmış, konunun önemine, gerekliliğine ve ihtiyaç olmasına dikkat çekilmiştir (10. Kalkınma Planı Yaşlanma Özel Ihtisas Komisyonu Raporu: 32-37). Plan'da yaşlılara yönelik evde bakım ihtiyacına vurgu yapılmış, bu ihtiyacın karşılanması hedefi şöyle ortaya konulmuştur: "(Madde) 285. Yaşlıların kendi çevrelerinden uzaklaşmadan evlerinde bakımını sağlamaya yönelik hizmetler çeşitlendirilerek yaygınlaştırılacak" (10. Kalkınma Planı: 44).

10. Kalkınma Planı'nın Yaşlılık ile ilgili bölümlerini hazırlayan Yaşlanma Özel İhtisas Komisyonu, raporunda "Evde Bakım" ile ilgili eylem planı, makalemizde dile getirdiğimiz olgulara şöyle dikkati çekmiştir: "Hedef: Bireylerin yaşamlarını geçirdikleri, anılarını biriktirdikleri yaşam alanlarında güvenli ve sağlıklı bir şekilde yaşlılık dönemlerini geçirebilmeleri için evde bakım hizmetlerinin organize edilmesi ve yaygınlaştırılması. Eylem 1: Yaşlıya yönelik evde sağlık ve sosyal bakım (kapsamlı evde bakım modeli) hizmetlerinin bütünleşik bir şekilde verilebilmesine yönelik kurumlar arasında işbirliğine gidilmesi ve koordinasyonun sağlanması. Eylem 2: Konuyla ilgili harcanan kaynakların etkin yönetiminin sağlanması. Eylem 3: Bu alanda bakım standartları, uygulama esasları ve denetim kriterlerinin oluşturulması; evde bakım hizmetlerinin yaygınlaştırılması. Eylem 4: Aile ve Sosyal Politikalar Bakanlığı tarafından verilen evde bakım parasından yararlanma koşullarının ve miktarlarının gözden geçirilmesi; evde bakım parasının özür durumuna göre farklılaşması, standartlarının geliştirilmesi, yararlanıcı kurumlara ve ailelere yapılan denetimlerin artırılması ve bu konuda ailelere gerekli eğitimlerin verilmesi için çalışmaların yapılması. Eylem 5: Özellikle evde yalnız kalan yaşlıların bakımında yurt dışındaki iyi uygulama modelleri dikkate alınarak bilişim teknolojilerinden yararlanılması" (10. Kalkınma Planı Yaşlanma Özel İhtisas Komisyonu Raporu: 54).

11. Kalkınma Planı (2019-2023), aynı olguya "Nüfus ve Yaşlanma" başlığında şu şekilde dikkati çeker: "(Madde) 655. Uzun süreli bakıma gereksinim duyan yaşl1lar için hizmetler çeşitlendirilecek ve yaygınlaştırılacaktır" (11. Kalkınma Planı: 167). Türkiye Cumhuriyeti Cumhurbaşkanlığı Strateji ve Bütçe Başkanlığı tarafından hazırlanan, 18 Temmuz 2019'da TBMM'de onaylanıp 23 Temmuz 2019'da Resmi Gazete'de yayımlanan 11. Kalkınma Planı (2019-2023)'nın "Nüfus ve Yaşlanma" başlığındaki ilgili maddelerin tamamı şöyledir: "(Madde) 655. Uzun süreli bakıma gereksinim duyan yaşlılar için hizmetler çeşitlendirilecek ve yaygınlaştırılacaktır. 655.1. Sürdürülebilir ve kapsayıcı bir bakım güvence modeli geliştirilecektir. 655.2. Farklı kurumlar tarafından sunulan uzun süreli evde bakım hizmetlerinde bütünlük ve kurumlar arası eşgüdüm sağlanacak, yerel yönetimlerin hizmet sunumunda daha fazla rol almasına imkân verecek düzenlemeler yapılacaktır. 655.3. Evde ve kurumsal yaşlı bakım hizmetlerinde çalışacak işgücünün nitelik ve niceliği artırılacaktır" (11. Kalkınma Planı: 146). Aşağıdaki maddeler de, başta bakanlıklar olmak üzere kurumlar arasındaki işbirliğinin önemine dikkat çekmesi bakımından önemlidir: "(Madde) 656. Yaşlılar için sağlik hizmetlerinin sunumu etkinleştirilecektir. 656.1. Sağlık hizmetlerinin sunumunda disiplinler arası bir yöntem geliştirilecek, geriatri alanında uzman personel sayısı artırılacak ve geriatrik hizmetler yaygınlaştırılacaktır" (11. Kalkınma Planı: 167, "Nüfus ve Yaşlanma"). "582.1. Evde sağlık hizmetleri yaygınlaştırılarak erişim, etkinlik ve kalite artırılacak ve yoğun bakım, palyatif bakım ve geriatri hizmetinin evde bakım hizmetleri ile entegrasyonu sağlanacaktır. 582.2. Yaşlılara yönelik sağlık izlemleri gerçekleştirilecek, yaşla birlikte artan 
hastalıklara ilişkin koruyucu ve tedavi edici hizmetler güçlendirilecek, geriatri ve palyatif bakım hizmetleri sunan merkezlerin sayısı artırılacaktır" (11. Kalkınma Plant: 146, "Sağlık"). Bütün olarak bakıldığında, "Ulusal Evde Bakım Sistemi” önerimiz için gerekli düşünce, plan-program ve uygulama alt-yapıs1, devlet kurumlarımızda mevcuttur.

\section{Değerlendirme ve Sonuç}

Türkiye'deki 7 milyonu aşan 65+ yaşlı nüfusu, bu nüfusun ihtiyaçları, hâlen işlemekte olan kurum bakımı (huzurevleri vd.) ve evde bakım uygulamaları birlikte düşünüldüğünde, elde edilen veriler, istatistikler ve bulgular mevcut sistemin bazı yönlerden yetersizliğini ortaya koymaktadır. Kurum bakımının, bakım ihtiyacı duyan yaşlı nüfusun isteklerini karşılamasının olanaksız olduğu, bunun yanında Türkiye'deki birey tipi ve toplum yapısı dikkate alındığında kurum bakımının kişilerin öncelikli tercihi olmadığı görülmektedir. Öte taraftan, maddi veriler incelendiğinde mevcut, merkezî, yerel, sivil toplum örgütleri ve özel kurumlar tarafından sağlanan evde bakım hizmetlerinin de yetersiz kaldığı ortaya çıkmaktadır. Geçici ve/veya sürekli olarak evde bakım ihtiyacı duyan dezavantajlı tüm grupların ihtiyaçlarının karşılanması noktasında, çeşitli alt-yapı olanaklarına rağmen organizasyona ve örgütlenmeye bağlı olarak genel bir yetersizliğin olduğu da görülmektedir. Bu tespitler 1şığında şunu söylemek mümkündür: Türkiye'deki mevcut $65+$ yaşlı nüfusu ve evde bakıma ihtiyaç duyan tüm dezavantajlı gruplar için yeni çözüm sistemleri ve uygulamaları gerekmektedir. "Ulusal Evde Bakım Sistemi” önerimiz, mevcut alt-yapı imkânları ile kurumlaştırılabilecek uygulanabilir bir çözüm seçeneği sunmaktadır.

Ortaya konulan koşullar, bakıma muhtaç bireylerin ihtiyaçları ve bakım hizmetinin karşıladığ hizmetler bağlamında şu olgu netleşmiştir: Türkiye, büyüyen yaşlı nüfusuna paralel olarak sosyal politikalar ve uygulamalar geliştirmelidir. Böylece, mevcut ve olası sosyal sorunların engellenmesi sağlanır. Yaşlılığa ve yaşlanmaya bağlı sosyal sorun alanındaki çözüm olanaklarını genişleten uygulamalardan bir tanesi "Evde Bakım Sistemi”dir. Evde Bakım Sistemi, sadece yaşlı bireyler için değil, bakıma muhtaç duruma gelen tüm bireyler (süreğen hastalar, engelliler, geçici engelli durumuna düşen bireyler, çocuklar vd.) için temel bir hizmet alanı ve çözüm uygulamasıdır.

Evde bakım, yaşl1, engelli, kronik hastalar, günümüzün yaşam dinamiklerinde çocuklar ve bütün dezavantajlı gruplar için temel bir ihtiyaçtır. Evde bakım gereksinimi, birey ve toplum refahı açısından tartışılmaz bir uygulamadır. Bu kapsamda; yaşlı bireylerin tatminlerini karşılayan sağlıklı, huzurlu, dengeli ve aktif bir yaşlanma için, yaşlı refahını artırmak temelinde, ekonomik ve konut sorunlarını dolaylı, sağlık, beslenme, yalnızlık ve izolasyon ile "bakım" sorununu doğrudan "iyileştirme" olanağına sahip, bireysel ve toplumsal refahı destekleyen, geliştiren ve yayan, nicel olarak yetersiz ve mevcut toplumsal yapı açısından işlevsel olmayan kurumsal bakım hizmetlerini tamamlayan, bireyi kendi yaşam alanı, ailesi ve toplum içerisinde destekleyerek birey-aile-toplum varoluş halkalarının sağlıklı bütünlüğünü sağlayan sosyal ilişkileri ve sosyal destek sistemlerini en güçlü biçimde harekete geçiren, ekonomik ve fiziksel çevre refahına destek olurken temelde fiziksel/bedensel, sosyal, duygusal/psikolojik ve manevi refahı doğrudan olumlu yönde etkileme gücüne sahip, Aile, Çalışma ve Sosyal Hizmetler Bakanlığı, Sağlık Bakanlığı, yerel yönetimler, sivil toplum örgütleri, özel kurumlar, gönüllü yapılar vd. tüm dikey ve yatay sağlik ve sosyal hizmet sistemleri ile eşgüdümlü ve bütünlüklü olarak, devlet kurumları tarafindan, kamu ve özel imkanlarla hizmet satın alma yoluyla veya diğer kamu, sivil toplum örgütleri, yerel yönetimler, özel ve gönüllü kurumların ortak uygulama programlarıyla faaliyetlerinin karşılanması olanağının olduğu, bu kurumların tümünü içeren "Ulusal Evde Bakım Sistemi”nin (UEBS) kurulması, Türkiye'nin aile yapısı, toplumsal dokusu, ekonomik verimlilik, mevcut olanaklar ve gündelik yaşam tercihleri, sağlık ve sosyal hizmet hedefleri bağlamında ihtiyaç duyulan, etkili, sürdürülebilir ve kalıcı bir çözümdür.

Bununla birlikte bir noktaya dikkati çekmek gerekir: Modernleşmenin etkisinde ve yükselen şehirleşme oranı ve buna bağlı şehir hayatının etkileri altında geleneksel aile yapısından çekirdek aileye yönelen toplumsal yapı, bununla birlikte aile fertlerinin çalışması, evde bakım desteğinin 
düşüklüğü ve sosyal sigorta desteğinin olmaması gibi diğer özellikler kapsamında bütüncül olarak bakıldığında, aile fertlerine dayalı "evde bakım" anlayışının her zaman olumlu olarak görülemeyeceği, bu sebeple şehirde yaşlanma süreçlerinin başka sosyal sorunları da beraberinde getirebileceği öngörülmelidir. Ulusal Evde Bakım Sistemi tasarlanırken bu olgular dikkate alınmalıdır. Öte taraftan dünyada onlarca yıldır uygulanan evde bakım sistemlerinden elde edilen deneyimlerden faydalanılmalı, buralardan gelen sonuçlar Türkiye'de yapılandırılacak sistemin inşasında veri olarak kullanılmalıdır. Nihayetinde, Ulusal Evde Bakım Sistemi, hem dünyadaki evde bakım birikiminden makro ve mikro planda faydalanarak güçlü biçimde tasarlanabilir hem de değişen aile yaşamı ile açığa çıkan birçok sosyal sorun alanı için farklı çözümler sunabilir.

Ulusal Evde Bakım Sistemi, yaşlıların bakım ihtiyacı odağında öne çıkmakla birlikte, engelli, geçici veya sürekli bakım ihtiyacı duyan ve duyabilecek olan dezavantajlı tüm gruplar ve bireyler için de işlevsel bir yapıdır. Tamamlayıcı yapılanma olarak "Ulusal Bütünleşik Sosyal Hizmet Sistemi” ile birleştirilecek "Ulusal Evde Bakım Sistemi”, Türkiye'deki sağlık ve sosyal hizmet uygulamalarının etkinliğini, kalitesini, verimliliğini ve yaygınlığını artıracaktır. Böylece, bütün sosyal hizmet uygulamalarını bir çatı altında toplayan ve "dezavantajlı bireyleri aileleri yanında ve aileleri ile birlikte toplumda refah içinde yaşatma" amacını taşıyan "Ulusal Bütünleşik Sosyal Hizmet Sistemi", etkili biçimde uygulanabilecektir.

\section{KAYNAKÇA}

4. Ulusal ve Uluslararası Katılımlı Evde Sağlı ve Bakım Kongresi (2017, 22-25 Kasım). http://evdebakim.org.tr/4-ulusal-ve-uluslararasi-katilimli-evde-saglik-ve-bakim-kongresi.html, İstanbul, E.t. 1 Mart 2019.

10. Kalkınma Planı (2014-2018) (2014). Ankara: Kalkınma Bakanlığı.

10. Kalkınma Planı Yaşlanma Özel İhtisas Komisyonu Raporu (2014-2018) (2014). Ankara: Kalkınma Bakanlığ 1 .

11. Kalkınma Planı (2019-2023) (2019, Temmuz). Ankara: Türkiye Cumhuriyeti Cumhurbaşkanlı̆̆ Strateji ve Bütçe Başkanlı̆̆ .

Aşar, R. Ş., Duman, K. N., Kapucu, S., Turgut, D. ve Yazıcı, C. (2018). Yaşlı Bireye Sahip Ailelerin Yaşlılık Hakkındaki Algıları (Yayımlanmamış Bitirme Tezi). İstanbul: Maltepe Üniversitesi İnsan ve Toplum Bilimleri Fakültesi Sosyal Hizmet Bölümü.

Aydın, D. (2005). Evde Bakım Hizmetleri. Ankara: Sağlıklı Nesiller Derneği.

Badur, T., Seven, N. ve Temel Z. (2015). Yaşlılara Yönelik Evde Bakım Hizmetlerinin Kamu, Yerel ve Özel Kurumlar Bağlamında Karşılaştırmalı İncelemesini Yapan Niteliksel Bir Araştırma (Yayımlanmamış Bitirme Tezi). İstanbul: Maltepe Üniversitesi İnsan ve Toplum Bilimleri Fakültesi Sosyal Hizmet Bölümü.

Barnay, T. ve Juin, S. (2016). Does home care for dependent elderly people improve their mental health?. Journal of Health Economics, Say1 45, s. 149-160.

Bayoğlu, A. S. (2011). Yaşlanma Sürecinde Sosyal Dışlanmaya Karşı Güçlendirme Temelli Sosyal Hizmet Müdahalesi. Sosyal Dışlanma ve Aile: Sosyal Hizmet Müdahalelerinde Güçlendirme Yaklaşımı (3. Bask1, 2011) içinde (s. 123-136). Ankara: Maya Akademi Yayınları.

Bekiroğlu, S. (2016). Türkiye'de Sağlık Hizmetleri Kapsamında Tibbi Sosyal Hizmet Uygulamaları. Sosyal Çalışma ve Sosyal Politika Yazıları içinde (s. 137-164) (Haz. İ. Cilga, E. Erkul, B. Yıldırım ve İ. B. Adıgüzel). Ankara: Bellek Yayınları. 
Bilge, U., Elçioğlu, Ö., Ünalacak, M. ve Ünlüoğlu, İ. (2014). Türkiye'de Yaşlı Evde Bakım Hizmetleri. Eurasian Journal of Family Medicine. Cilt 3, Sayı 1, s. 1-8.

Birleşmiş Milletler Yaşlı İlkeleri, 16 Aralık 1991.

Boissy, P., Corriveau, H., Michaud, F., Labonté, D. ve Royer, M.P. (2007). A qualitative study of inhome robotic telepresence for home care of community-living elderly subjects. Journal of Telemedicine and Telecare, Cilt 13, Say1 2, s. 79-84.

Bruce, M. L., McAvay, G. J., Raue, P. J., Brown, E. L., Meyers, B. S., Keohane, D. J., Jagoda, D. R. ve Weber, C. (2002). Major Depression in Elderly Home Health Care Patients. The American Journal of Psychiatry, Say1 159, s. 1367-1374.

Can, M. (2013). Günümüz Refah Politikaları Bağlamında Sosyal Hizmetlerin Farklı Modelleri: Dünya Örnekleri Üzerine Bir Değerlendirme. Ankara: Nobel Yayınları.

Caris-Verhallen, W. M. C. M., Kerkstra, A., van der Heijden P. G. M. ve Bensing, J. M. (1998). Nurse-elderly patient communication in home care and institutional care: an explorative study. International Journal of Nursing Studies, Say1 35, s. 95-108.

Caro, F. G. ve Blank, A. E. (1985). Effects of Home Care on the Qualityof Circumstances of the Elderly. Gerontological Society of America'nın yıllık toplantısinda sunulan rapor, 30 sayfa.

Cheung, K. M. (1988, Mart). Home Care Services for the Elderly: Cost Savings Implications to Medicaid. Social Services Review, The University of Chicago, s. 127-136.

Cravens, D. D., Mehr, D. R. Campbell, J. D., Armer, J., Kruse, R. L. ve Rubenstein, L. Z. (2005). Home-based Comprehensive Assessment of Rural Elderly Persons: The CARE Project. The Journal of Rural Health, Cilt 21, Say1 4, s. 322-328.

Çağlar, T. (2015). Türkiye ve Almanya'da Karşılaştırmalı Yaşlı Bakım Model ve Uygulamaları (Yayımlanmamış Doktora Tezi). Ankara: Hacettepe Üniversitesi Sosyal Bilimler Enstitüsü.

Çağlar, T. (2015, 26-28 Kasım). Yaşlı Bakım Alanında Alternatif Bir Sistem: Almanya Bakım Sigortas1 (Bildiri) (Sosyal Hizmet Sempozyumu 2015). Manisa: Manisa Celal Bayar Üniversitesi.

Çağlar, T. (2017). Yaşlı Bakımı: Modeller ve Uygulamalar. Ankara: Nika Yayınları.

Çav, E. (2015, 26-28 Kasım). Bir Sosyal Sorun Alanı Olarak Yaşlı Refahı ve Kapsayıcı Bir Çözüm Önerisi: Evde Bakım Sistemi (Bildiri) (Sosyal Hizmet Sempozyumu 2015). Manisa: Celal Bayar Üniversitesi.

Çavuş, F. Ö. (2013). Yaşlılara Yönelik Evde Bakım Hizmetlerinin Değerlendirilmesi (Yayımlanmamış Yüksek Lisans Tezi). Ankara: Hacettepe Üniversitesi Sosyal Bilimler Enstitüsü Sosyal Hizmet Anabilim Dalı.

Çoban, M. ve Esatoğlu, A. E. (2004). Evde Bakım Hizmetlerine Genel Bir Bakış. Türkiye Klinikleri Tip Etiği-Hukuku-Tarihi Dergisi, Sayı 12, s. 109-120.

Daenzer, P. M. (2009). Canada: New Ideology and Social Assistance in Post-industrial Society. The Welfare State in Post-Industrial Society içinde (s. 235-251) (Ed. J. L. Powel ve J. Hendricks). New York: Springer.

Dağdelen, G. (2016). Sosyal Sorunlar ve Sosyal Çalışma. Sosyal Çalışma ve Sosyal Politika Yazıları içinde (s. 61-82) (Haz. İ. Cılga, E. Erkul, B. Yıldırım ve İ. B. Adıgüzel). Ankara: Bellek Yayınları. 
De Lange, F. (2018). Is home the best place to be old? The changing geography of responsibilities in the care for elderly. Stellenbosch Teological Journal, Cilt 4, Say1 1, s. 133-151.

Dölek, B. Ö. (2013). Gerontolojik ve Geriatrik Sosyal Hizmet. Sosyal Politika ve Kamu Yönetimi Bileşenleriyle Sosyal Hizmet Temelleri ve Uygulama Alanları içinde (s. 279-297) (Ed. H. Acar, N. Negiz ve E. Akman). Ankara: Maya Akademi.

Duyan, V., Sayar, Ö. Ö. ve Özbulut, M. (2008). Sosyal Hizmeti Tanımak ve Anlamak. Ankara: Öncü Basımevi.

Easterbrook, L. (2002). Moving on from Community Care. London: Age Concern Books.

Easterbrook, L. (2007). Your Rights to Health Care (2. Bask1). London: Age Concern Books.

Easterbrook, L. https://www.lornaeasterbrookconsultancy.com/publications.html, E.t. 31 May1s 2019.

Elbaş, N. Ö. ve Arpacı, F. (2004). Yaşıı Bireyin Evde Sağlık Bakımı. Yaşlılık Disiplinlerarası Yaklaşım, Sorunlar, Çözümler içinde (s. 119-134) (Ed. V. Kalınkara). Ankara: Odak Yayınları.

Elin, N. (2019, 14 Mart). Aile Hekimliğinde Yaşlı Sağlı̆̆ Hizmetleri. İstanbul: 1. Uluslararası Aktif Yaşlanma ve Kuşaklararası Dayanışma Kongresi.

Engelli ve Yaşlı Bireylere İlişkin İstatistiki Bilgiler (2019, Ocak). TUİK.

Engeström, Y., Nummijoki, J. ve Sannino, A. (2012). Embodied Germ Cell at Work: Building an Expansive Concept of Physical Mobility in Home Care. Mind, Culture, and Activity, Say1 19, s. 287-309.

Eraslan, A., Sakarya, F., Çubukçuoğlu, H. Ögat, B., Sevil, H. T., Aslan, M., İnce, İ., Seydibeyoğlu, T., Tunacan J., Eroğlu, K., Hablemitoğlu, Ş., Gönen, E. ve Şengül, Ş. (1995). Yaşl1lık ve Sosyal Hizmetler Grup Raporu (4. Ulusal Sosyal Hizmetler Sempozyumu). 2000'li Ylllara Doğru Sosyal Devletin Gerçekleştirilmesinde Sosyal Hizmetlerin Yeri ve Önemi içinde (s. 231-235). Ankara: Sosyal Hizmet Uzmanları Derneği Yayını.

Ersanlı, K. ve Kalkan, M. (Ed.) (2008). Psikolojik, Sosyal ve Bedensel Açıdan Yaşlılık. Ankara: Pegem Akademi.

Evans, C. J., Goodman, C. ve Redfern, S. (2003). Maintaining independence in the cognitively intact elderly care home population: a systematic review of intervention trials. Reviews in Clinical Gerontology, Say1 13, s. 163-174.

Evde Sağlık ve Sosyal Hizmetlerin Bütünleşmesi Sempozyumu Raporu (2013, 18-19 Eylül) İstanbul: Evde Bakım Derneği.

Fabris, F., Molaschi, M., Aimonino, N., Ponzetto, M., Maero, B., Tibaldi, V., Nicola, E., Varetto, O., Barresi, O., Cavallero, M. L., Boschis, D., Plastino, V. ve Vitale, R. (2004). Home Care For Demented Subjects: New Models Of Care And Home-Care Allowance. Archives of Gerontology and Geriatrics, Say1 9, s. 155-162.

Fahey, T., Montgomery, A. A., Barnes, J. ve Protheroe, J. (2003). Quality of care for elderly residents in nursing homes and elderly people living at home: controlled observational study. The BMJ, Say1 326, s. 1-5.

Gelmez, Ö. S. Ö. (2015). Ailevileştirilen bakımın kürek mahkûmları: Evde bakım uygulaması kapsamında bakım veren kadınların deneyimleri. Fe Dergi: Feminist Eleştiri, Cilt 7, Sayı 2, s. $59-71$. 
Gelmez, Ö. S. Ö. (2016, 16 Aralık). Bakım Emeği Sömürüsünün Özneleri ya da Bir Sosyal Politika Uygulamasının Nesneleştirdikleri: Evde Bakım Uygulaması Kapsamında Bakım Veren Kadınlar. Hacettepe Üniversitesi Sosyolojik Araştırmalar E-Dergisi. Ankara (Sayı ve sayfa sayısı yok).

Hablemitoğlu, Ş. ve Özmete, E. (2010). Yaşlı Refahı-Yaşlılar İçin Sosyal Hizmet. Ankara: Kilit Yayınları.

Hellström, Y. ve Hallberg, I. R. (2001). Perspectives of elderly people receiving home help on health, care and quality of life. Health and Social Care in the Community, Cilt 9, Say1 2, s. 67-71.

Hori, T., Nishida, Y., Aizawa, H., Murakami, S. ve Mizoguchi, H. (2004). Sensor Network for Supporting Elderly Care Home. International Conference on Industrial Informatics (IEEE) 2004 Konferans Bildiri Kitab1, s. 575-578.

İstanbul Yaşlılık Çalıştayı Kitabı (2012). İstanbul: İstanbul Büyükşehir Belediyesi.

Istatistiklerle Yaşlılar 2014 (2015, 18 Mart 2015). Ankara: TUIKK Yayınlar.

İstatistiklerle Yaşlılar 2018 (2019, 18 Mart). Ankara: TUíK Yayınları.

Kalınkara, V. (2011). Temel Gerontoloji Yaşlılık Bilimi. Ankara: Nobel Yayınları.

Kalwij, A., Pasini, G. ve Wu, M. (2009, 16 Temmuz). Home Care for the Elderly: Family, Friends, and the State (Discussion Paper-Tartışma Makalesi). Network for Studies on Pensions, Aging and Retirement (NETSPAR), 45 sayfa.

Keigher, S. M., Simon-Rusinowitz, L., Linsk, N. L. ve Osterbuch, S. E. (1988). Payments to Informal versus Formal Home Care Providers: Policy Divergence Affecting the Elderly and Their Families in Michigan and Illinois. The Journal of Applied Gerontology, Cilt 7, Say1 4, s. 456473.

Kesselring, A., Krulik, T., Bichsel, M., Minder, C., Beck, J. C. ve Stuck, A. E. (2001). Emotional and physical demands on caregivers in home care to the elderly in Switzerland and their relationship to nursing home admission. Eurpean Journal of Public Health, Cilt 11, Say1 3, 267-273.

Kleisiaris, C., Maniou, M., Papathanasiou, I., Sfiniadaki, A., Collaku, E., Koutsoumpa, C. ve Sarafis, P. (2013). The prevalence of depressive symptoms in an elderly population and their relation to life situations in home care. Healt Science Journal, Cilt 7, Say1 4, s. 417-423.

Laan, G. (2001). Avrupa Birliğine Giriş Sürecinde Türkiye'de Sosyal Politikalar (Panel). Sosyal Hizmet Sempozyumu 2000 içinde (s. 95-127). (Haz. İ. Tomanbay). Ankara: Hacettepe Üniversitesi Sosyal Hizmetler Yüksek Okulu Yayınları.

Lagana, M. T. C., Malveira, F. A. S., Melo, J. K. F., Silva, R. T. S., Carvalho, R. F. ve Cabral, A. M. F. (2013). Strategy For Innovation In The Teaching Of Nursing In The Home Care For The Elderly. Journal of Research Fundamental Care On Line, Cilt 5, Say1 3, s. 293-303.

Mou, H. ve Winer, S. L. (2012). Fiscal Incidence when both Individual Welfare and Family Structure Matter: The Case of Subsidization of Home-Care for the Elderly. CESifo Working Papers No. 3731, 32 sayfa.

Nachabe, L., Girod-Genet, M., ElHassan, B. ve Khawaja, J. (2016). Ontology Based Tele-Health Smart Home Care System: Ontosmart to Monitor Elderly. Computer Science \& Information Technology içinde (s. 43-59) (Ed. N. Meghanathan). CS \& IT-CSCP. 
Oğlak, S. (2016). Evde Bakımın İhmal Edilen Boyutu: Sosyal Bakım. Türkiye Klinikleri. Cilt 2, Sayı 3, s. 32-37.

Onarcan, M. (2011, 2 Ağustos). Türkiye'de Evde Bakım Hizmetleri ve Ülke Modeli İçin Öneriler. http://www.sdplatform.com/Dergi/519/Turkiyede-evde-bakim-hizmetleri-ve-ulke-modeli-icinoneriler.aspx, E.t. 1 Mart 2019.

Otero, A., Yebenes, M. J. G., Laso, A. R. ve Victoria, M. (2003). Unmet home care needs among community-dwelling elderly people in Spain. Aging Clinical and Experimental Research, Cilt 15, Say1 3, s. 235-242.

Özer, Ö. ve Şantaş, F. (2012). Kamunun Sunduğu Evde Bakım Hizmetleri ve Finansmanı. Acıbadem Üniversitesi Sağlık Bilimleri Dergisi, Cilt 3, Sayı: 2, s. 96-103.

Pajalic, Z., Persson, L., Westergren, A. ve Skovdahl, K. (2012). Public home care professionals' experiences of being involved in food distribution to home-living elderly people in Sweden - a qualitative study with an action research approach. Journal of Nursing Education and Practice, Cilt 2, No 2, s. 1-11.

Richmond, K. ve Mias, C. (2005). Home Care in Serbia-Montenegro. The British Red Cross Society, 33 sayfa.

Qadeer, N., Velik, R. Zucker, G. ve Boley, H. (2009). Knowledge Representation for a NeuroSymbolic Network in Home Care Risk Identification. 7. Uluslararasi Endüstriyel Bilim Konferansı (IEEE International Conference on Industrial Informatics) Bildiriler Kitabı içinde (s. 277-282).

Sevil, H. T. (2005). Yaşlılığın Sosyal Anatomisi. Ankara: Sabev Yayınları.

Seyyar, A. (2006). Özürlülere Adanmış Sosyal Politika Yazıları. Adapazarı: Adapazarı Büyükşehir Belediyesi Yayınları.

Seyyar, A. (2007). Bakıma Muhtaç Kişilere Dönük Manevi Bakım Uygulamaları. Manevi Sosyal Hizmetler içinde (s. 141-175) (Haz. A. Seyyar). İstanbul: Rağbet Yayınları.

Seyyar, A. ve Genç, Y. (2010). Sosyal Hizmet Terimleri (Ansiklopedik "Sosyal Pedagojik Çalışma" Sözlüğ̈̈). Sakarya: Sakarya Yayıncılık.

Sipila, J. (2009). A Nordic Welfare State in Post-industrial Society. The Welfare State in PostIndustrial Society içinde (s. 181-199) (Ed. J. L. Powel ve J. Hendricks). New York: Springer.

Taşc1, F. (2014). Refah Devleti ve Yaşlılık Algıs1: Türkiye Üzerinden Değerlendirmeler. Dezavantajlı Gruplar ve Sosyal Politika içinde (s. 35-56) (Haz. B. Altuntaş). Ankara: Nobel Yayınları.

Thiruchelvam, V. ve Teng, C. T. (2015). Home Automation for Elderly Home Stay. Uluslararası Elektrik ve Elektronik Mühendisliği Telekomünikasyon Mühendisliği ve Mekatronik Konferansı Bildirileri, Malezya: SDIWC.

Turner, K. J., Docherty, L. S., Wang, F. ve Campbell, G. A. (2009). Managing Home Care Networks. Proc. 8th Int. Conf. on Networks içinde (s. 354-359) (Ed. R. Bestak, L. George, V. S. Zaborovsky ve C. Dini), IEEE Computer Society.

Uluocak, Ş. ve Aslan, C. (2012). Toplum ve Engelliler. Çanakkale: Çanakkale Kitaplığı.

Vukovic, D. (2013). Social Economy, Civil Society And The Serbian Welfare System. Cooperatives and Social Enterprises in Europe and in Transitional Contexts içinde (s. 62-78) (Ed. S. Cvejic). Belgrad: European Research Institute on Cooperative and Social Enterprises.

Weinstein, S. M. (1987, Mayis-Haziran). Regulatory Concerns: Home Care. NITA. 
Wilkins, K. ve Park, E. (1998). Home Care in Canada. Health Reports, Cilt 10, Say1 1, s. 29-37.

Yerel Yönetimler ve Sosyal Hizmetler (1998). Ankara: Türk Belediyecilik Derneği ve Konrad Adenauer Vakfi.

Yücel, N. (2009). Demanslı Yıllara Değer Katan Aktiviteler (2. Baskı). İstanbul: İBB Yayınları.

Zastrow, C. (2013). Sosyal Hizmete Giriş (Çev. Kolektif). Ankara: Nika Yayınları. 